\title{
Opioid Inhibition of Hippocampal Interneurons via Modulation of Potassium and Hyperpolarization-Activated Cation $\left(I_{h}\right)$ Currents
}

\author{
Kurt R. Svoboda ${ }^{1}$ and Carl R. Lupica ${ }^{1,2}$ \\ ${ }^{1}$ Department of Pharmacology and ${ }^{2}$ Program in Neuroscience, University of Colorado Health Sciences Center, \\ Denver, Colorado 80262
}

\begin{abstract}
The actions of mu- and delta-opioid agonists (DAMGO and DPDPE, respectively) on GABAergic interneurons in stratum oriens of area CA1 of the hippocampus were examined by using whole-cell voltage-clamp recordings in brain slices. Both agonists consistently generated outward currents of similar magnitude (15-20 pA) in the majority of cells. However, under control conditions, current-voltage (I/V) relationships revealed that only a small number of these cells (3 of 77) demonstrated clear increases in membrane conductance, associated with the activation of the potassium current known as $G_{\text {irk }}$. These interneurons also exhibited a slowly activating, inwardly rectifying current known as $I_{\mathrm{h}}$ on hyperpolarizing step commands. $I_{\mathrm{h}}$ was blocked by the extracellular application of cesium (3-9 mM) or ZD $7288(10-100 \mu \mathrm{M})$ but was insensitive to barium (1-2 mM). In an effort to determine whether the holding current changes were attributable to the modulation of $G_{\text {irk }}$ and/or $I_{h}$, we used
\end{abstract}

known blockers of these ion channels (barium or cesium and ZD 7288, respectively). Extracellular application of cesium (3-9 $\mathrm{mm})$ or ZD $7288(25-100 \mu \mathrm{M})$ blocked $I_{\mathrm{h}}$ and significantly reduced the opioid-induced outward currents by $58 \%$. Under these conditions the opioid agonists activated a potassium current with characteristics similar to $G_{\text {irk }}$. Similarly, during barium (1-2 mm) application the opioid-induced outward currents were reduced by $46 \%$, and a clear reduction in $I_{\mathrm{h}}$ and the whole-cell conductance was revealed. These data suggest that the opioids can modulate both $I_{\mathrm{h}}$ and $G_{\text {irk }}$ in the same population of stratum oriens interneurons and that the modulation of these ion channels can contribute to the inhibition of interneuron activity in the hippocampus.

Key words: delta-receptor; electrophysiology; enkephalin; GABA; hippocampus; opioid receptor; mu-receptor; nonselective cation current; oriens/alveus interneurons; queer current
Opioid receptors are members of a class of $\mathrm{G}_{\mathrm{i}} / \mathrm{G}_{\mathrm{o}}$-coupled receptors that inhibit both adenylyl cyclase and voltage-dependent $\mathrm{Ca}^{2+}$ channels (VDCCs) in central and peripheral neurons (Childers, 1993; Moises et al., 1994). In addition to these actions, opioids activate a G-protein-coupled inwardly rectifying potassium conductance known as $G_{\text {irk }}$, resulting in the hyperpolarization of neurons throughout the CNS (Williams et al., 1982; Madison and Nicoll, 1988; North, 1989; Wimpey and Chavkin, 1991). These opioid effects on ion channels generally inhibit neuronal activity. However, in some cellular circuits, when the opioid-sensitive neuron releases an inhibitory neurotransmitter such as GABA, the net result can be the excitation or disinhibition of the postsynaptic neuron. Such is the case for the principal cells of the CA1 region of the hippocampus, where opioids produce profound increases in pyramidal neuron activity after the inhibition of GABA release from local circuit inhibitory interneurons (Zieglgansberger et al., 1979; Lee et al., 1980; Nicoll et al., 1980; Pang and Rose, 1989; Lupica and Dunwiddie, 1991). These interneurons constitute only $10-20 \%$ of the neuronal population in the hippocampus and are heterogeneous with regard to their membrane properties, neurotransmitter sensitivity, and neuropeptide content (for review, see Freund and Buzsáki, 1996).

\footnotetext{
Received April 10, 1998; revised June 18, 1998; accepted June 24, 1998.

This work was supported by National Institutes of Health Grant DA 07725, United States Public Health Service. We thank Drs. Thomas Dunwiddie, Kevin Staley, and Jeffrey Weiner for their remarks on this manuscript and Dr. Cathy Adams for assistance with the biocytin assays.

Correspondence should be addressed to Dr. Carl R. Lupica, Department of Pharmacology, Box C236, University of Colorado Health Sciences Center, 4200 East Ninth Avenue, Denver, CO 80262.

Copyright () 1998 Society for Neuroscience $\quad 0270-6474 / 98 / 187084-15 \$ 05.00 / 0$
}

However, these cells exert pandemic control over hippocampal activity, because they each make multiple synaptic contacts on hundreds of principal neurons.

Although it is likely that opioids play an important role in the modulation of processes like learning and memory, epilepsy, and drug reinforcement via actions on interneurons in the hippocampus (Siggins et al., 1986; Stevens et al., 1991; Xie and Lewis, 1991), there have been few direct studies of opioid effects on these cells. Most have relied, instead, on indirect measures such as GABA-mediated IPSPs/IPSCs from pyramidal cells (Lee et al., 1980; Nicoll et al., 1980; Cohen et al., 1992; Lupica et al., 1992; Lupica, 1995). To date, studies using direct recordings from CA1 interneurons have examined only the effects of opioids on $\mathrm{K}^{+}$ channels and VDCCs (Madison and Nicoll, 1988; Wimpey and Chavkin, 1991; Lambert and Wilson, 1996). These investigators found that $G_{\text {irk }}$ was activated by the $\mu$-selective agonist DAMGO in acutely dissociated CA1/subicular interneurons (Wimpey and Chavkin, 1991) or by a nonselective opioid agonist (D-Ala ${ }^{2}-\mathrm{Met}^{5}$ enkephalinamide) in stratum pyramidale interneurons (Madison and Nicoll, 1988). However, another study found that DAMGO did not activate $G_{\text {irk }}$, nor did it inhibit VDCCs in stratum radiatum interneurons (Lambert and Wilson, 1996).

Another conductance that is prominent in hippocampal interneurons found in stratum oriens is known as $I_{\mathrm{h}}$ (Maccaferri and McBain, 1996). This slowly developing inward cation current is activated by hyperpolarization, is carried by $\mathrm{Na}^{+}$and $\mathrm{K}^{+}$ions, and does not inactivate, even with prolonged hyperpolarization (Halliwell and Adams, 1982; Mayer and Westbrook, 1983; Maccaferri and McBain, 1996). Because of these characteristics, $I_{\mathrm{h}}$ probably contributes to the resting membrane potential and the 
generation of rhythmic pacemaker-like depolarizations in central neurons and cardiac cells (DiFrancesco, 1981; Bal and McCormick, 1996; Maccaferri and McBain, 1996; Gasparini and DiFrancesco, 1997) (for review, see Pape, 1996). Therefore, modulation of $I_{\mathrm{h}}$ by neurotransmitters would be expected to alter the oscillatory activity of individual neurons and, in turn, the network of cells with which they communicate (Freund and Buzsáki, 1996) (for review, see Pape, 1996). In addition, because of its properties, $I_{\mathrm{h}}$ might interact with other conductances by opposing the membrane hyperpolarization initiated by inhibitory neurotransmitters. Among the several neuromodulators that modulate $I_{\mathrm{h}}$ are the opioids, which inhibit this current in peripheral neurons by inhibiting adenylyl cyclase (Ingram and Williams, 1994). However, at this time no studies of the opioid modulation of $I_{\mathrm{h}}$ in central neurons have been described. In the present investigation we demonstrate that $\mu$-and $\delta$-opioid receptor agonists inhibit $I_{\mathrm{h}}$ and activate $G_{\text {irk }}$ in the same hippocampal interneurons, and we postulate that these effects contribute to the sustained inhibition of interneuron activity by the opioids.

\section{MATERIALS AND METHODS}

Electrophysiology. Hippocampal slices were prepared and maintained as previously described (Miller et al., 1997). Briefly, 14- to 30-d-old male Sprague Dawley rats (Sasco, Omaha, NE) were killed by rapid decapitation. Their brains were removed and placed in ice-cold oxygenated artificial CSF (aCSF; see below). Brain slices containing the hippocampus were cut transverse to the anterior-posterior axis at $300 \mu \mathrm{m}$ nominal thickness, using a vibrating tissue slicer (Technical Products International, St. Louis, MO). Then the slices were suspended on netting in a beaker containing aCSF that was aerated continuously with $95 \% \mathrm{O}_{2} / 5 \%$ $\mathrm{CO}_{2}$ at room temperature. Control aCSF consisted of (in mM): 126 $\mathrm{NaCl}, 3.0 \mathrm{KCl}, 1.5 \mathrm{MgCl}_{2}, 2.4 \mathrm{CaCl}_{2}, 1.2 \mathrm{NaH}_{2} \mathrm{PO}_{4}, 11.0$ glucose, and 26 $\mathrm{NaHCO}_{3}$, saturated with $95 \% \mathrm{O}_{2} / 5 \% \mathrm{CO}_{2}$. Interneurons were visualized in stratum oriens of area $\mathrm{CA} 1$, using a fixed stage upright microscope equipped with differential interference contrast optics and infrared illumination, as previously described in detail (Miller et al., 1997). Whole-cell recordings were obtained at room temperature $\left(20-23^{\circ} \mathrm{C}\right)$ with an Axopatch-200A amplifier (Axon Instruments, Foster City, CA) and electrodes pulled from thick-walled borosilicate capillary tubing (inner diameter, $0.75 \mathrm{~mm}$; outer diameter, $1.5 \mathrm{~mm}$; Sutter Instrument, Novato, CA). The electrodes had resistances of 4-7 $\mathrm{M} \Omega$ when filled with (in $\mathrm{mM}$ ): $125.0 \mathrm{~K}$-gluconate, $10.0 \mathrm{KCl}, 10.0 \mathrm{HEPES}, 1.0 \mathrm{EGTA}, 0.1$ $\mathrm{CaCl}_{2}, 2.0 \mathrm{Mg}^{2+}$-ATP, and $0.2 \mathrm{Na}^{+}$-GTP (adjusted to pH 7.2-7.4 with $1 \mathrm{M} \mathrm{KOH}$, and brought to $270-280 \mathrm{mOsm}$ with de-ionized water). The reversal potential for $\mathrm{K}^{+}$currents $\left(E_{\mathrm{K}}\right)$ using these stated internal (135.0 $\mathrm{mM})$ and external $(3.0 \mathrm{mM}) \mathrm{K}^{+}$concentrations was predicted to be approximately $-96 \mathrm{mV}$ at $20^{\circ} \mathrm{C}$, according to the Nernst equation. Unless otherwise stated, all interneurons were voltage-clamped at $-66 \mathrm{mV}$ after correction for a liquid junction potential. Series resistance was generally $<15 \mathrm{M} \Omega$ and was monitored throughout the experiments by using the capacitative currents generated by small $(-5$ to $-10 \mathrm{mV}, 250 \mathrm{msec})$ voltage steps. Cells were rejected from analysis if the series resistance changed by $\geq 10-15 \%$. Voltage-clamp protocols were delivered by a pulse generator (Master 8, A.M.P.I., Jerusalem, Israel), and signals were acquired by a PC-based data acquisition system (Strathclyde Electrophysiology Software, courtesy of John Dempster, Strathclyde University, UK).

Histology. Biocytin (0.25\%; Sigma, St. Louis, MO) was added to the internal solution for post hoc evaluation of the anatomical location of the neurons. A majority of the interneuron recordings were $>1 \mathrm{hr}$ in duration. In these cases, at the end of the recording period the patch pipette was withdrawn slowly from the slice, which then was transferred to chilled $\left(4^{\circ} \mathrm{C}\right) 4 \%$ paraformaldehyde in PBS. In recordings of shorter duration the pipette was left in place in the slice, and the preparation was left undisturbed in the recording chamber for an additional one-half hour to permit diffusion of biocytin into the cell. Slices were stored in the chilled fixative for 3-7 d. After fixation, they were rinsed in PBS (three times for $5 \mathrm{~min}$ ) and then exposed to avidin-biotin horseradish peroxidase complex (ABC, Vector Laboratories, Burlingame, CA) for $4 \mathrm{~d}$. On the fourth day, they were rinsed again in PBS and then incubated in $0.04 \%$ diaminobenzidine (DAB) for 20-30 min. The DAB reaction was stopped by rinsing in PBS. Then the slices were dehydrated in incrementing concentrations of ethanol $(70,95,100,100 \%)$. After dehydration, they were cleared in Hemo-D (three times for $5 \mathrm{~min}$ ) and then mounted on slides. Cells were reconstructed with the aid of a camera lucida drawing tube attached to an Olympus microscope.

Chemicals. Drugs were obtained from the following sources: DPDPE (D-Pen ${ }^{2}, \mathrm{D}-\mathrm{Pen}^{5}$-enkephalin) and DAMGO (Tyr-D-Ala ${ }^{2}, \mathrm{~N}-\mathrm{CH}_{3}$ Phe ${ }^{4}$,Gly-ol-enkephalin), National Institute on Drug Abuse Drug Supply System (Rockville, MD); tetrodotoxin (TTX), Alomone Laboratories (Jerusalem, Israel) or Sigma; $\mathrm{CsCl}$ and $\mathrm{BaCl}_{2}$ (Sigma); ZD 7288, Tocris Cookson (Ballwin, MO). All drugs and channel blocking agents were made at 100 times their final concentration in de-ionized water and added to the aCSF bathing the slice (flow rate $=2 \mathrm{ml} / \mathrm{min}$ ) with calibrated syringe pumps (Razel Scientific Instruments, Stamford, CT).

\section{RESULTS}

\section{Morphology}

All of the recordings were obtained from neurons that had somata located within stratum oriens of the CA1 region of the hippocampus. Previous studies have shown that a vast majority of neurons found outside of stratum pyramidale are positive for glutamic acid decarboxylase (GAD) and, therefore, GABAergic (Somogyi et al., 1983; Frotscher et al., 1984; Kunkel et al., 1986). The morphology of the stratum oriens cells was diverse, and the axonal arborizations were, in many cases, elaborate. The axons of several of these cells extended through all CA1 layers, and no consistent patterns of termination were noted. Although the axonal distribution pattern was diverse, most of the interneurons possessed multiple dendritic processes restricted primarily to stratum oriens. A few of these cells exhibited dendrites extending into the alveus (Fig. 1). The morphology of these cells with somata and dendrites confined to stratum oriens is consistent with previous descriptions (Lacaille et al., 1987; McBain et al., 1994; Zhang and McBain, 1995). Examples of two biocytin-filled interneurons reconstructed with the use of camera lucida are shown in Figure 1.

\section{Opioids generate outward currents in stratum oriens interneurons}

Bath application of the selective $\mu$-opioid receptor agonist DAMGO $(1 \mu \mathrm{M})$ or the selective $\delta$-agonist DPDPE $(1 \mu \mathrm{M})$ generated reversible outward currents in the majority of stratum oriens interneurons. Of the 66 interneurons in which DPDPE was tested, $40(60.6 \%)$ responded with outward currents, whereas 24 of $55(43.6 \%)$ neurons that were tested were sensitive to DAMGO. The magnitudes of the outward currents were similar with either agonist (Fig. 2A). Only 12 of 44 neurons $(27 \%)$ that were tested responded to both agonists.

In neurons throughout the CNS, opioid-generated outward currents reverse near the $\mathrm{K}^{+}$equilibrium potential $\left(E_{\mathrm{K}}\right)$ and usually are associated with an increase in membrane conductance because of the activation of a G-protein-coupled $\mathrm{K}^{+}$channel known as $G_{\text {irk }}$ (Williams et al., 1982; Madison and Nicoll, 1988; North, 1989; Wimpey and Chavkin, 1991). However, in the present study, when the effects of DAMGO and DPDPE were examined on current-voltage $(I / V)$ relationships (using $250 \mathrm{msec}$ voltage steps from -66 to $-136 \mathrm{mV}$ ) (Fig. $2 B$ ), we found that there was either very little change in the whole-cell conductance or a small net decrease, despite the clear change in holding current (control $=7.1 \pm 0.6 \mathrm{nS}$, pooled DPDPE and DAMGO = $6.8 \pm 0.7 \mathrm{nS} ; n=17$; measured at steady state from the linear portion of the $I / V$ curves). This is illustrated in Figure $2 C$, in which both DPDPE and DAMGO produced changes in the $I / V$ curves during the peak outward currents that were inconsistent 


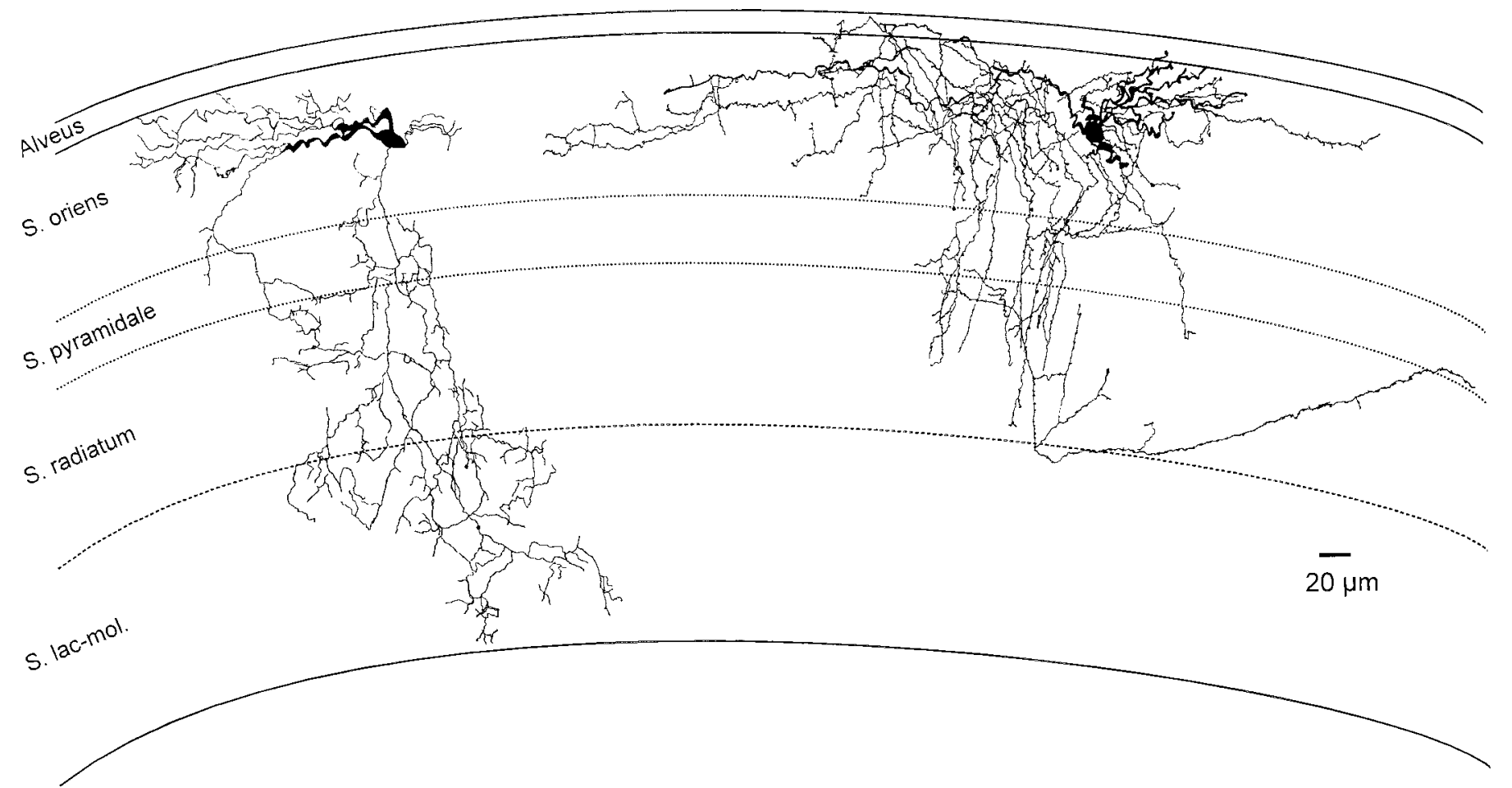

Figure 1. Camera lucida reconstructions of two biocytin-filled CA1 stratum oriens interneurons that were included in the data set shown in Figure 2. The large majority of these neurons had dendritic processes confined to stratum oriens and demonstrated axons projecting to all of the major hippocampal strata. The data shown in Figure $2 B$ were obtained from the cell on the left of this figure.

with an increase in whole-cell conductance expected to result from the activation of a $\mathrm{K}^{+}$channel like $G_{\text {irk }}$. To evaluate whether these neurons were capable of generating outward currents associated with the activation of $G_{\text {irk }}$, we compared the actions of the $\mathrm{GABA}_{\mathrm{B}}$ receptor agonist baclofen, which is known to activate this conductance (Gahwiler and Brown, 1985; Inoue et al., 1985; Newberry and Nicoll, 1985; Christie and North, 1988), with the opioid agonists in the same interneurons. At a holding potential of $-66 \mathrm{mV}$, baclofen $(60 \mu \mathrm{M})$ generated outward currents $(25.0 \pm 4.7 \mathrm{pA}, n=7)$ that were associated with an increase in membrane conductance of $1.7 \pm 0.5 \mathrm{nS}$ (Fig. 3 ). In addition, the $E_{\mathrm{rev}}$ for the baclofen-induced current was $-91.1 \pm 4.1 \mathrm{mV}$, which is close to the calculated $E_{\mathrm{K}}$ of $-96 \mathrm{mV}$. These data indicated that, whereas both the opioid and $\mathrm{GABA}_{\mathrm{B}}$ receptor agonists produced outward currents, only baclofen activated an apparent $\mathrm{K}^{+}$channel associated with an increase in membrane conductance and characteristics similar to $G_{\text {irk }}$ (compare Fig. $3 B, C$ ). A small number of the stratum oriens interneurons ( 8 of $94,8.5 \%$ ) exhibited current responses to voltage steps hyperpolarized to approximately $-76 \mathrm{mV}$ that lacked the prominent inward sag that is indicative of the hyperpolarization-activated cation current known as $I_{\mathrm{h}}$ (visible in Fig. $2 B$ ). Of those eight neurons lacking $I_{\mathrm{h}}$, three demonstrated clear outward currents on opioid application. In each of these cells the $I / V$ curves revealed that the opioid-sensitive currents reversed near $E_{\mathrm{K}}$ and were associated with an increase in membrane conductance, consistent with the activation of $G_{\text {irk }}$ (Fig. 4).

\section{Characteristics of $\boldsymbol{I}_{\mathrm{h}}$ in stratum oriens interneurons}

The hyperpolarization-activated cation current, $I_{\mathrm{h}}$, is known to activate slowly and displays virtually no time-dependent inactivation during a voltage step (Mayer and Westbrook, 1983; Mac- caferri and McBain, 1996; Watts et al., 1996). In addition, in most preparations $I_{\mathrm{h}}$ is not active at membrane potentials positive to approximately -55 to $-75 \mathrm{mV}$, and it typically does not saturate at potentials as negative as $-155 \mathrm{mV}$ (Maccaferri and McBain, 1996; Watts et al., 1996). The slow activation kinetics of $I_{\mathrm{h}}$ suggest that this current should be larger at the end of a $2 \mathrm{sec}$ voltage step, at which point $I_{\mathrm{h}}$ is fully active (i.e., steady state, $I_{\mathrm{ss}}$ ), compared with the current observed near the beginning of a hyperpolarizing voltage step (i.e., the instantaneous current, $I_{\text {ins }}$ ), where the contribution of $I_{\mathrm{h}}$ is smaller. Similarly, the voltage-dependent nature of $I_{\mathrm{h}}$ suggests that the effects of modulators of this current should be seen at membrane voltages within its range of activation (i.e., negative to $-55 \mathrm{mV}$ ). This can be seen in Figure 5 in which the effects of extracellularly applied ZD $7288(25 \mu \mathrm{M})$ and cesium $(3 \mathrm{~mm})$, both blockers of $I_{\mathrm{h}}$, have been examined on the instantaneous and steady-state currents. Further isolation of these effects on $I_{\mathrm{h}}$ was achieved by subtracting $I_{\text {ins }}$ from $I_{\mathrm{ss}}$ at each voltage step, in the presence and absence of the modulator, using the following equation:

$$
\text { subtracted } I_{h}=\left[\left(I_{\mathrm{ss}_{\mathrm{m}}}-I_{\mathrm{ins}_{\mathrm{m}}}\right)-\left(I_{\mathrm{ss}_{\mathrm{c}}}-I_{\mathrm{ins}_{\mathrm{c}}}\right)\right],
$$

where $I_{\mathrm{ss}_{\mathrm{m}}}$ and $I_{\mathrm{ins}_{\mathrm{m}}}$ are the steady-state and instantaneous currents measured in the presence of the modulator, and $I_{\mathrm{ss}_{\mathrm{c}}}$ and $I_{\mathrm{ins}}$ are these currents in the control condition. $I_{\mathrm{ss}}$ was inhibited to a greater extent than $I_{\text {ins }}$ by both cesium and ZD 7288 (shown for ZD 7288 in Fig. 5B), and the cesium- and ZD 7288-sensitive currents were more prominent at step potentials more negative than approximately $-75 \mathrm{mV}$ (Fig. 5C).

Voltage steps greater than $-136 \mathrm{mV}$ caused a rapid degradation of the recordings and, therefore, were not used routinely. Overall, cesium (3-9 mM) decreased the whole-cell conductance 
A

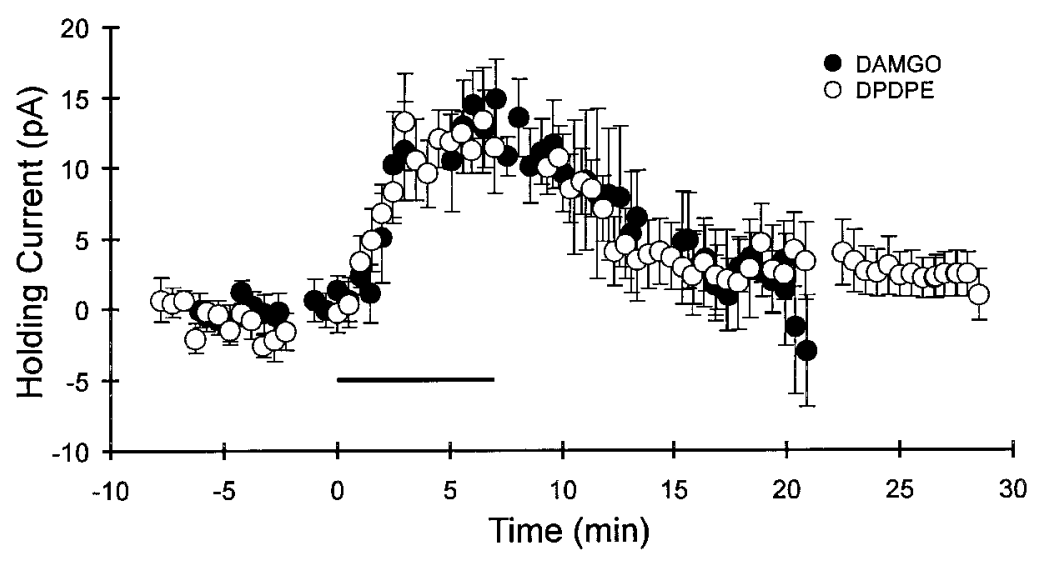

B
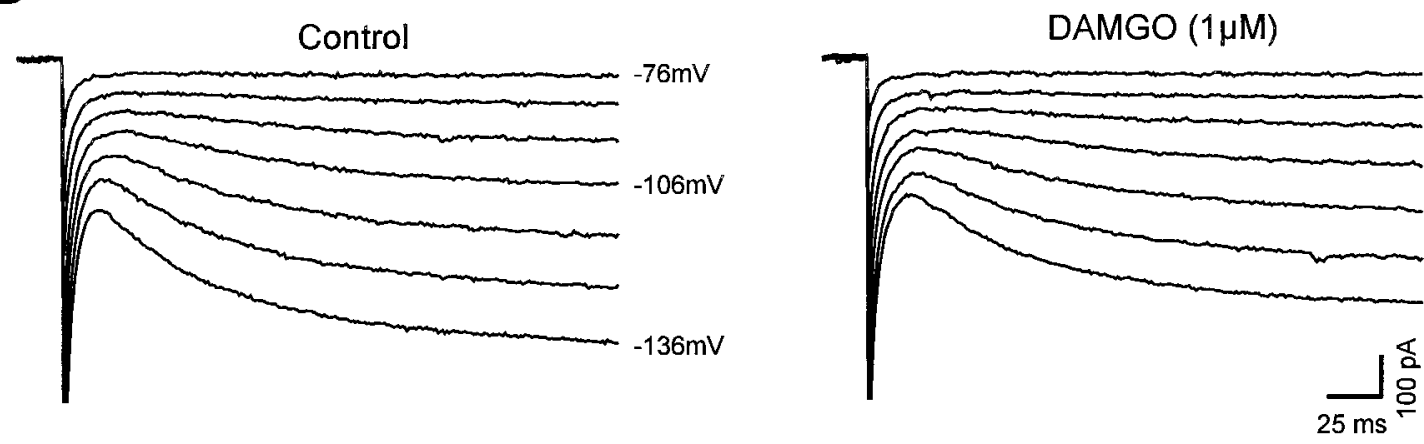

C
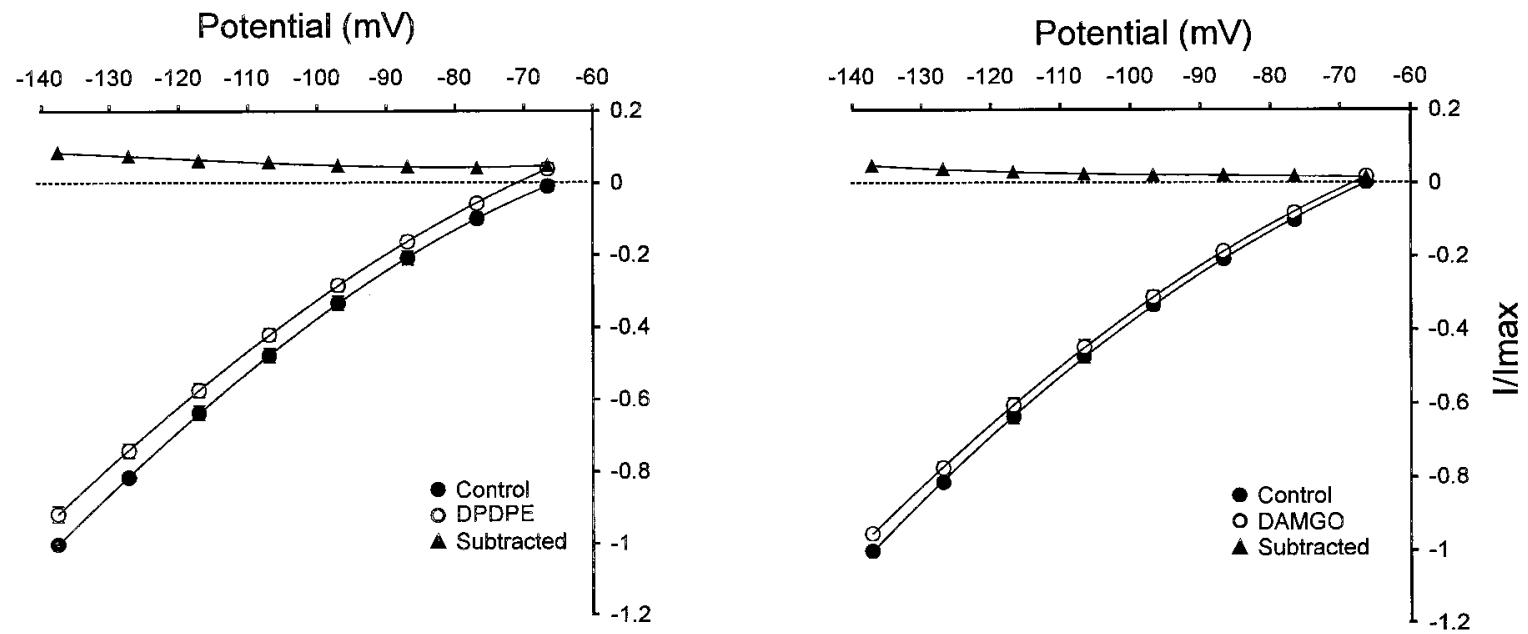

Figure 2. Effects of selective $\mu$-opioid $(D A M G O, 1 \mu \mathrm{M} ; n=12)$ and $\delta$-opioid (DPDPE, $1 \mu \mathrm{M} ; n=12)$ agonists on interneurons with somata located in stratum oriens of area CA1 in hippocampal slices. $A$, Time course of mean \pm SEM opioid-induced outward currents. All neurons were voltage-clamped at $-66 \mathrm{mV}$. The horizontal bar indicates the duration of the opioid agonist bath application. $B$, Current responses obtained from a single interneuron before (Control) and during DAMGO application that was used in the construction of the curves shown in $C$ (right panel). Voltage steps (250 msec in duration, $10 \mathrm{mV}$ increments) from -66 to $-136 \mathrm{mV}$ were used to produce these responses. Note the prominent voltage- and time-dependent inward sag in the current responses at progressively hyperpolarized voltage steps. $C$, Mean \pm SEM effect of $\delta$ - and $\mu$-agonists on current-voltage $(I / V)$ relationships obtained during the peaks of the holding current changes shown in $A$. All data were normalized to the largest current response that was obtained by using a $250 \mathrm{msec}$ voltage step to $-136 \mathrm{mV}\left(I / I_{\text {max }}\right)$. In this and subsequent figures the points labeled Subtracted $(\mathbf{\Delta})$ indicate the drug-induced change in current obtained by subtracting the control points from those measured during drug application. 
A

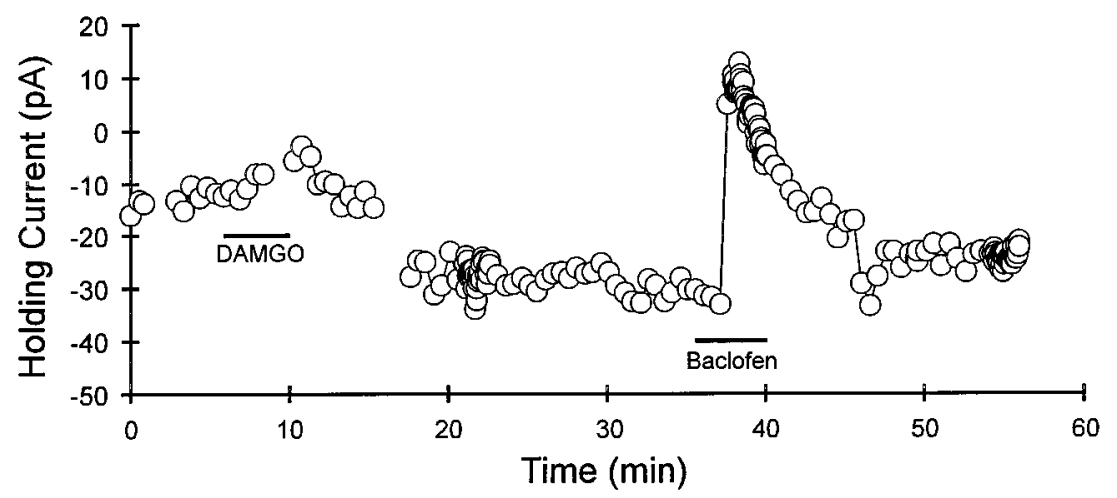

B

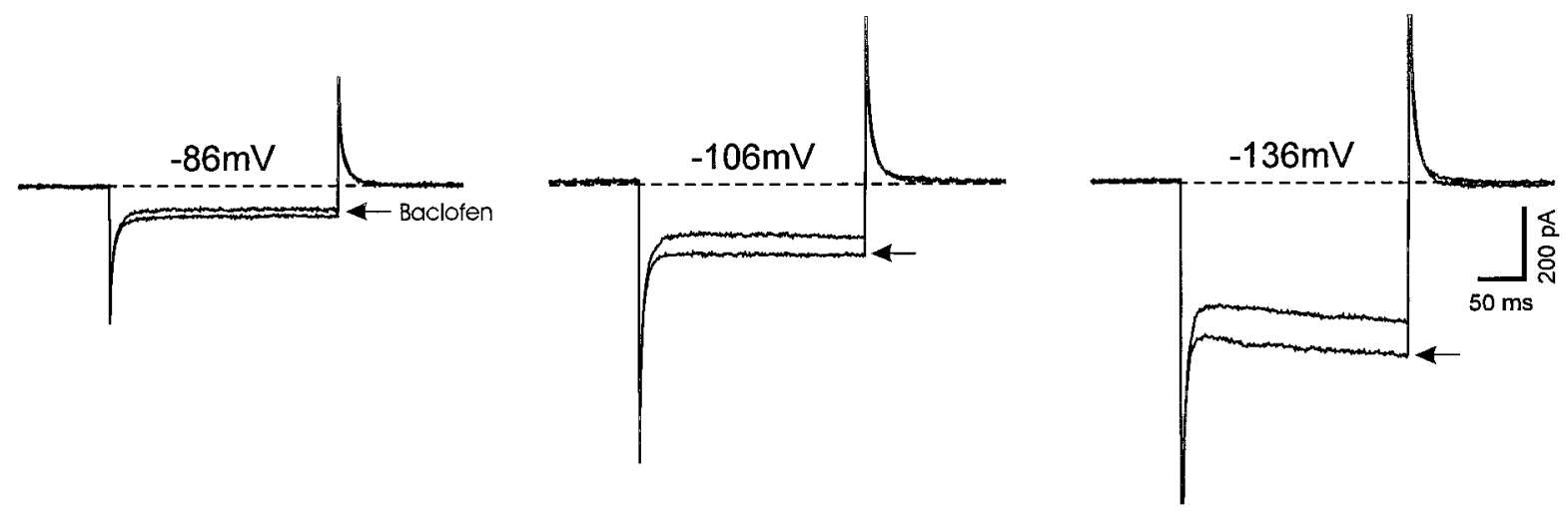

C

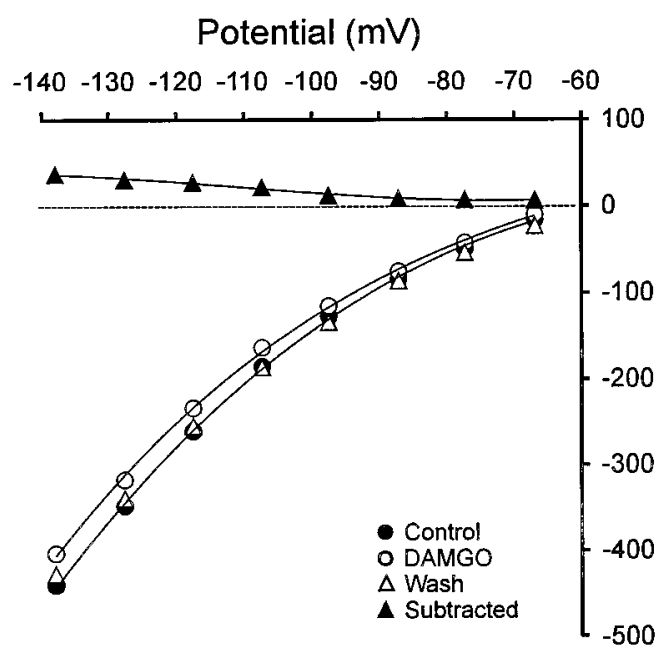

D

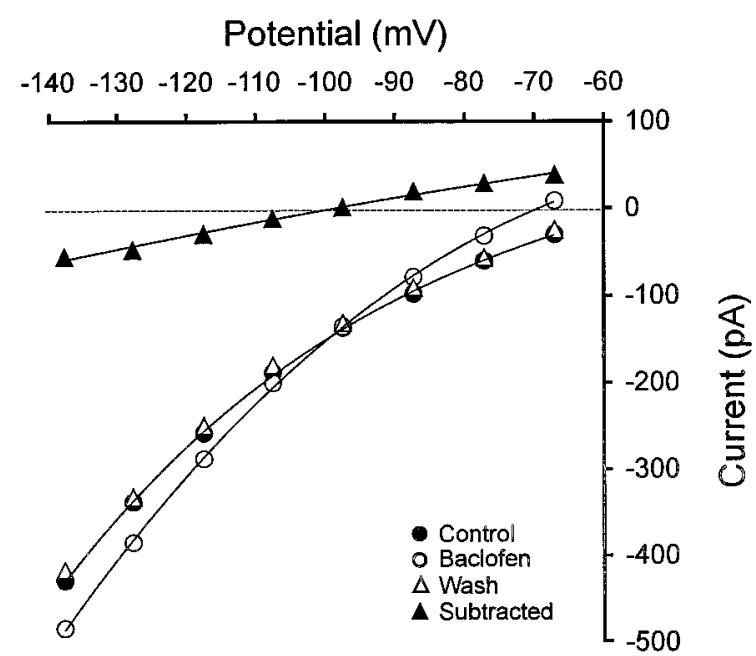

Figure 3. Effects of the $\mu$-opioid agonist DAMGO $(1 \mu \mathrm{M})$ and the $\mathrm{GABA}_{\mathrm{B}}$ agonist baclofen $(60 \mu \mathrm{M})$ on a stratum oriens interneuron. $A$, Time course of DAMGO- and baclofen-induced outward currents in a neuron voltage-clamped at $-66 \mathrm{mV}$. $B$, Individual current responses obtained before and during baclofen application (arrows) at the indicated voltage steps. $C, I / V$ curve $(250 \mathrm{msec}$ steps between -66 and $-136 \mathrm{mV})$ constructed before (Control), during, and $\sim 7$ min after (Wash) DAMGO application. Note the larger effect of DAMGO on currents produced at more hyperpolarized steps and the complete washout of this effect. $D, I / V$ curve constructed before (Control), during, and after (Wash) baclofen application. The reversal potential for this baclofen-induced current $(-100 \mathrm{mV})$ is near $E_{\mathrm{K}}(-96 \mathrm{mV})$ in these cells. All data are derived from the same neuron, and the gaps in the records in $A$ are attributable to the construction of the $I / V$ curves. 
A

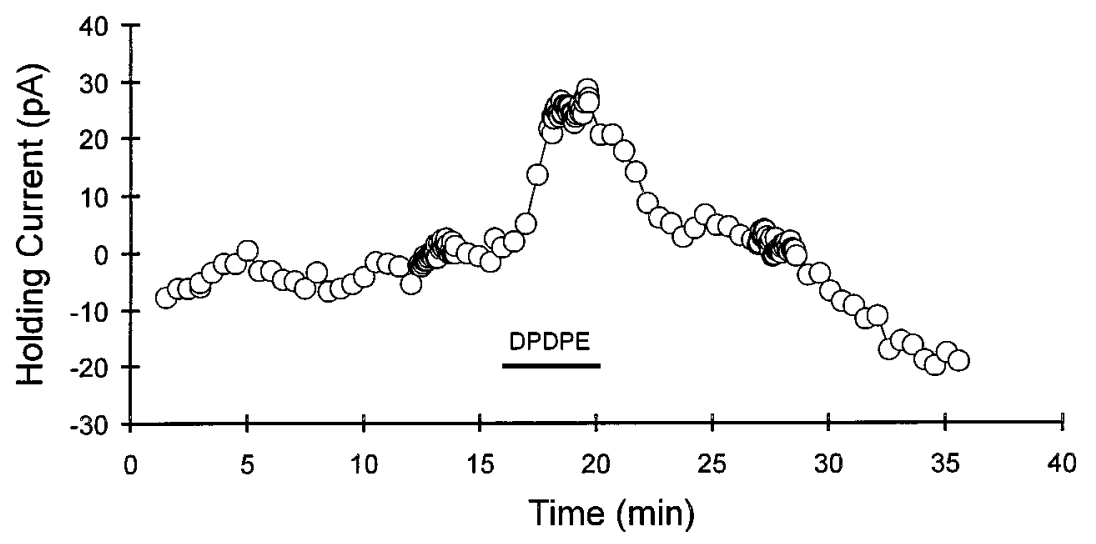

B1

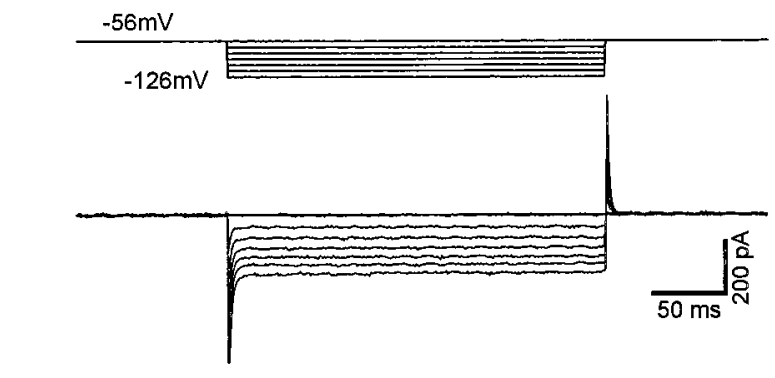

B2
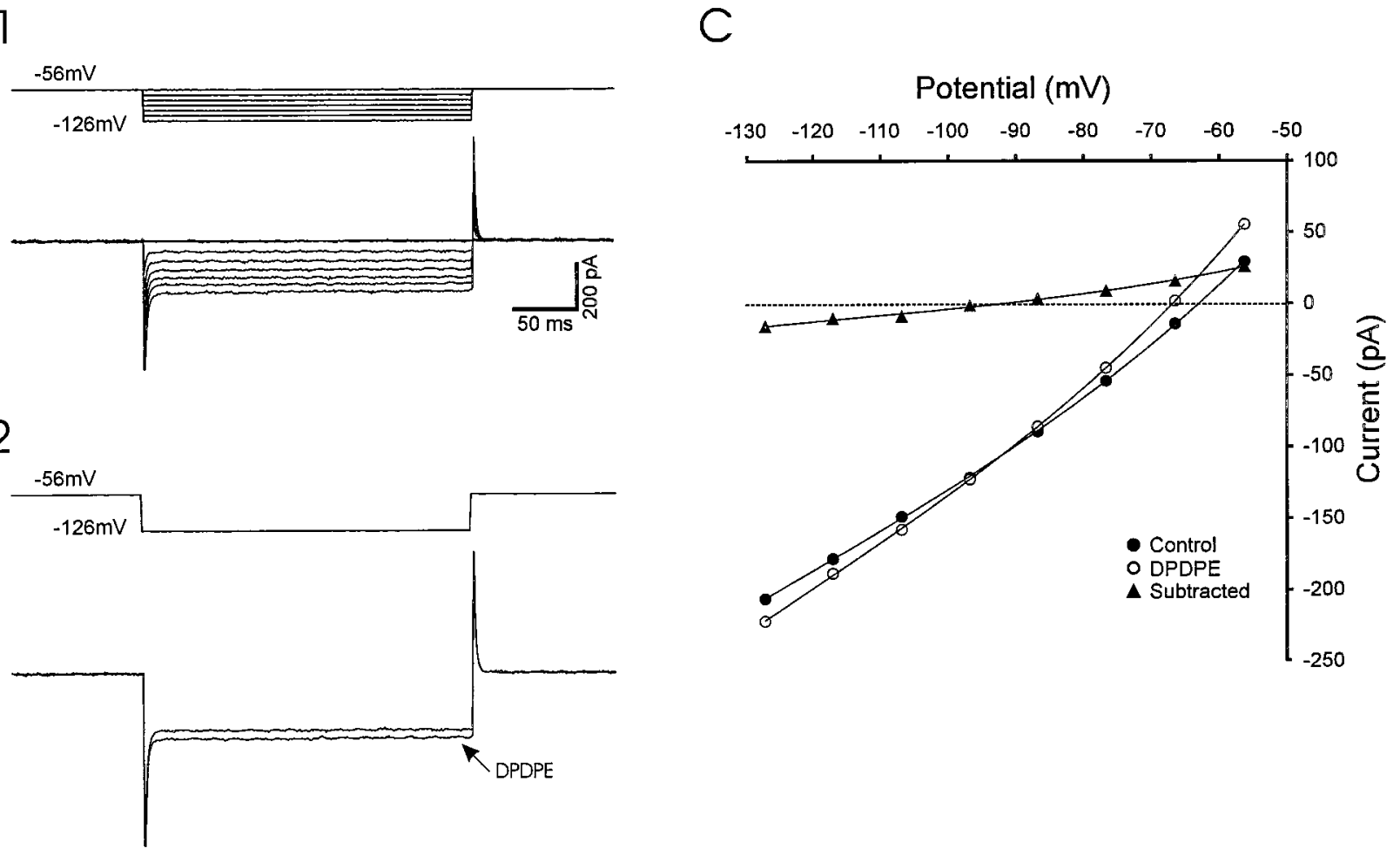

Figure 4. The $\delta$-agonist DPDPE $(1 \mu \mathrm{M})$ activates an apparent $\mathrm{K}^{+}$current in a stratum oriens interneuron lacking $I_{\mathrm{h}}$. $A$, Time course of DPDPE-induced outward current in a neuron voltage-clamped at $-56 \mathrm{mV}$. B1, Voltage and current traces obtained $\sim 3$ min before DPDPE application. B2, Current responses obtained before and during DPDPE (arrow) application at the largest voltage step $(-126 \mathrm{mV})$. Note the absence of the inward current sag (compare with Fig. 2) and the larger current response during DPDPE application. The holding current change was subtracted from the trace obtained in DPDPE to demonstrate more clearly the change in conductance. $C$, Current-voltage relationships determined in the same neuron as described in $A$ and $B$. The DPDPE-sensitive current reversed near $E_{\mathrm{K}}$ (predicted $=-96 \mathrm{mV}$; measured $=-95.5 \mathrm{mV}$ ) and was associated with an increase in whole-cell slope conductance. Only 8 of $94(8.5 \%)$ stratum oriens neurons showed a similar absence of inward sag in the current response, and only 3 of these 8 neurons responded to opioid agonists with a similar apparent increase in $\mathrm{K}^{+}$conductance.

by $\sim 60 \%$ (control $=7.1 \pm 1.1 \mathrm{nS} ;$ cesium $=4.3 \pm 0.85 \mathrm{nS} ; n=$ 6 ), indicating that the contribution of $I_{\mathrm{h}}$ to the total whole-cell conductance was substantial. Consistent with previous reports, the block of $I_{\mathrm{h}}$ by ZD 7288 began after 4-7 min of superfusion, and a maximal blockade was achieved after 20-50 min (Harris and Constanti, 1995; Maccaferri and McBain, 1996; Gasparini and DiFrancesco, 1997). A complete block of $I_{\mathrm{h}}$ by cesium was achieved only at concentrations $>3 \mathrm{~mm}$ but was seen much more rapidly (3-5 $\mathrm{min}$ ) than with $\mathrm{ZD} 7288$ (data not shown). In addition to the alteration in whole-cell conductance, cesium also generated outward currents ranging from 3.5 to $19 \mathrm{pA}$ in amplitude $($ mean $=7.5 \pm 2.0 \mathrm{pA} ; n=8)$, suggesting that $I_{\mathrm{h}}$ may be activated partially in some interneurons at a clamp potential of $-66 \mathrm{mV}$. These effects of extracellular cesium are consistent with previous reports demonstrating the blockade of $I_{\mathrm{h}}$ in other preparations (Mayer and Westbrook, 1983; McCormick and Pape, 1990; Bal and McCormick, 1996). The reversal potential of $I_{\mathrm{h}}$ $\left(E_{\mathrm{h}}\right)$ was measured by using the method described by Mayer and 

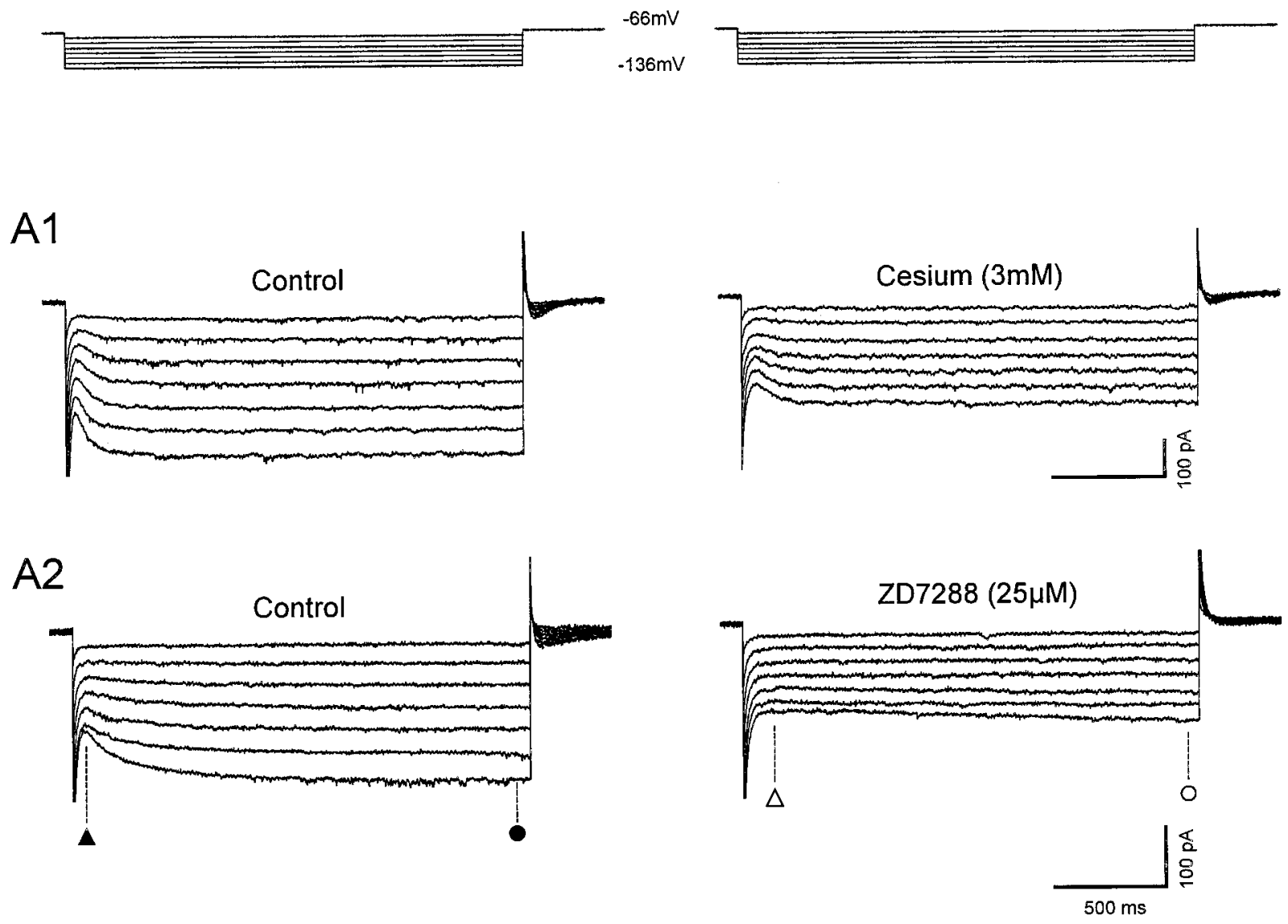

B
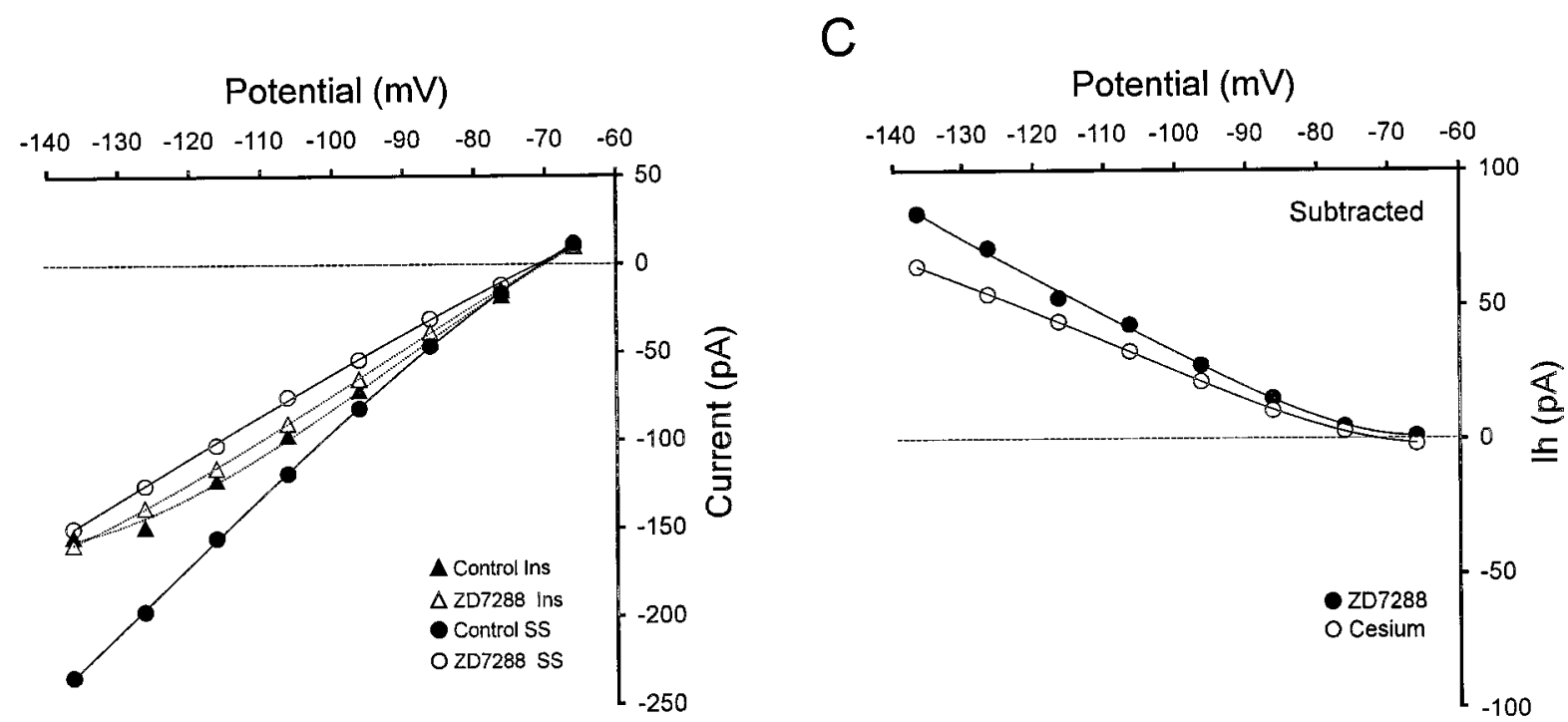

Figure 5. Effects of extracellularly applied cesium (3 mM) and ZD $7288(25 \mu \mathrm{M})$ on current responses in stratum oriens interneurons. $A$, Current records obtained during $2 \mathrm{sec}$ hyperpolarizing voltage steps from -66 to $-136 \mathrm{mV}$ in the absence (Control) or presence of cesium $(A 1)$ or $\mathrm{ZD}$ 7288 (A2). B, I/V relationship demonstrating the effect of ZD 7288 on the instantaneous (ins; Control Ins, $\mathbf{\Delta} ; \mathrm{ZD} 7288, \triangle$ ) and steady-state currents (ss; Control SS, - ZD 7288, $\bigcirc$ ). $C$, Cesium- and ZD 7288-sensitive $I_{\mathrm{h}}$ obtained by subtracting the instantaneous $I / V$ relationship from the steady-state $I / V$ relationship in the absence and presence of the blocking agent. Note that both cesium and ZD 7288 had a larger effect on the steady-state versus the instantaneous currents and that both inhibited a similar current with an activation threshold near $-75 \mathrm{mV}$. The symbols in $B$ correspond to those shown in $A 2$. 
Westbrook (1983). Thus, instantaneous $I / V$ curves were generated by six to eight voltage steps $(2 \mathrm{sec})$ from holding potentials of -56 , in which $I_{\mathrm{h}}$ is minimally active, and $-96 \mathrm{mV}$, in which $I_{\mathrm{h}}$ is activated substantially. Then the intersection of the extrapolated $I / V$ curves was used as the estimate of $E_{\mathrm{h}}$. The estimate of $E_{\mathrm{h}}$ obtained by using this method was $-33.0 \pm 2.0 \mathrm{mV}(n=7)$, which is similar to the value previously reported in these interneurons (Maccaferri and McBain, 1996).

\section{Opioids inhibit $\boldsymbol{I}_{\mathrm{h}}$ in stratum oriens interneurons}

When the effects of DAMGO $(1 \mu \mathrm{M})$ and DPDPE $(1 \mu \mathrm{M})$ were examined on currents evoked by 2 sec hyperpolarizing voltage steps, it was found that in some neurons, similar to the effects of cesium and ZD 7288, $I_{\mathrm{ss}}$ was inhibited to a larger extent than $I_{\text {ins }}$ at voltage steps between approximately -76 and $-136 \mathrm{mV}$ (Fig. 6B,C). Thus, the opioid-sensitive $I_{\mathrm{h}}$ currents were similar to those that were sensitive to ZD 7288 and cesium (compare Figs. 5C, 6D).

This is also evident in Figure 7, in which the current responses that were inhibited by ZD $7288(25 \mu \mathrm{M})$, cesium $(3 \mathrm{mM})$, and DPDPE $(1 \mu \mathrm{M})$ are shown $\left(V_{\text {hold }}=-66 \mathrm{mV}\right)$. Here it can be seen more clearly that the current inhibited by ZD 7288 and cesium is similar in its kinetic activation and voltage dependence to that inhibited by DPDPE. Exponential time constants (see below) fit to these currents at the largest hyperpolarizing voltage steps also indicate that the time course of these inhibited currents was similar (Fig. 7, legend). This suggests that all of these agents inhibited a current possessing the same temporal characteristics as $I_{\mathrm{h}}$. In contrast, the currents that were modulated by baclofen $(60 \mu \mathrm{M})$ are clearly different from those modulated by the inhibitors of $I_{\mathrm{h}}$ (Fig. 7D).

Because a previous report has suggested that the inhibition of $I_{\mathrm{h}}$ by baclofen may be secondary to $G_{\text {irk }}$ activation (Watts et al., 1996) and because it was unclear whether the modulation of $G_{\text {irk }}$ or $I_{\mathrm{h}}$ was responsible for the opioid-induced outward currents in the present study, barium was used to block the opioid activation of $G_{\text {irk }}$ and to permit an assessment of opioid effects on $I_{\mathrm{h}}$ in relative isolation. These experiments, and those using cesium (below), were conducted in the presence of the $\mathrm{Na}^{+}$channel blocker tetrodotoxin (TTX) to enhance the stability of the recordings and to determine whether the effects of DPDPE and DAMGO were direct. Outward currents were generated reliably by the opioids in the presence of TTX, whether administered with barium or cesium (below). Alone, bath application of barium (1-2 $\mathrm{mm})$ caused a decrease in membrane conductance of $1.8 \pm 0.5 \mathrm{nS}$ $(n=8)$ (Fig. $8 B)$. The $E_{\text {rev }}$ of the current that was inhibited by barium (measured at steady state, using $2 \mathrm{sec}$ voltage steps) was $-91 \pm 3.2 \mathrm{mV}$, suggesting that, in agreement with previous reports, barium blocked voltage-dependent $\mathrm{K}^{+}$channels (e.g., $I_{\mathrm{IR}}$ ) (Hille, 1992), and $I_{\mathrm{h}}$ was, in large part, unaffected (Halliwell and Adams, 1982; Mayer and Westbrook, 1983; Maccaferri and McBain, 1996). To evaluate the effects of barium on the opioid response, we established sensitivity to DPDPE or DAMGO; then we washed the opioid from the preparation and applied it again in the presence of barium (Fig. 8A). Wherever possible, the effect of the opioid also was evaluated after barium was washed from the preparation (Fig. 8A1). Barium was found to have two major effects on the opioid response. First, in every cell, barium significantly reduced the amplitude of the outward currents generated by DPDPE and DAMGO (Fig. 9A). However, these currents were reduced only to $45.8 \pm 8.8 \%$ of control $(p<0.05$; paired Student's $t$ test; $n=5$ ) (see Figs. 8A1, 11). Second, when the effects of the opioids were evaluated by the use of $I / V$ curves in the presence of barium, it was found that they caused a decrease in the remaining whole-cell conductance in every cell that was tested, with a mean \pm SEM reduction of $24.4 \pm 5.7 \%(n=8)$ (Figs. $8 D, 9 B)$. The reduction in $I_{\mathrm{h}}$ caused by the opioids in barium was manifest as a $55.2 \pm 7.2 \%$ decrease at $-86 \mathrm{mV}$ and a $29.3 \pm 9.8 \%$ decrease at $-136 \mathrm{mV}(n=8)$. In addition, the shape of the subtracted opioid-sensitive current was similar to that obtained for $I_{\mathrm{h}}$, as defined in the ZD 7288 and cesium experiments (see Fig. 5C).

The effect of the opioid agonists on the time constant of $I_{\mathrm{h}}$ activation also was determined in a subset of opioid-sensitive interneurons. The activation of $I_{\mathrm{h}}$ was studied by evoking current responses to voltage steps ( $2 \mathrm{sec}$ ) between -86 and $-136 \mathrm{mV}$ from a holding potential of $-66 \mathrm{mV}$. Then the inward sag associated with $I_{\mathrm{h}}$ activation was fit by using exponential functions of the form:

$$
I_{\mathrm{t}}=I_{\mathrm{ss}}+I_{\mathrm{h}} \mathrm{e}^{-t / \tau},
$$

where $I_{\mathrm{t}}$ is the amplitude of the current at time $t, I_{\mathrm{ss}}$ is the steady-state current measured at the end of a 2 sec voltage step, $I_{\mathrm{h}}$ is $I_{\text {ins }}$ subtracted from $I_{\mathrm{ss}}$, and $\tau$ is the time constant of activation. The rate of $I_{\mathrm{h}}$ activation demonstrated strong voltage dependence, with control time constants of $0.551 \pm 0.134 \mathrm{sec}$ at the $-96 \mathrm{mV}$ voltage step and $0.196 \pm 0.036 \mathrm{sec}$ at the $-116 \mathrm{mV}$ voltage step $(n=8)$. The opioid agonists significantly $(p<0.001$; paired $t$ test) slowed the activation of $I_{\mathrm{h}}$, such that the time constants were $1.36 \pm 0.122 \mathrm{sec}$ at $-96 \mathrm{mV}$ and $0.45 \pm 0.059 \mathrm{sec}$ at $-116 \mathrm{mV}$. Collectively, these results suggest that, when $G_{\text {irk }}$ was blocked by the addition of barium, the opioids consistently decreased the whole-cell conductance and slowed the rate of $I_{\mathrm{h}}$ activation. In addition, the persistence of the opioid effect on $I_{\mathrm{h}}$ in the presence of TTX suggests that it resulted from the direct stimulation of opioid receptors located on the interneurons.

\section{Opioids activate $\mathrm{K}^{+}$channels in stratum oriens interneurons}

In an effort to determine whether the activation of $G_{\text {irk }}$ by the opioids was obscured by the concomitant inhibition of $I_{\mathrm{h}}$, we examined the effects of DPDPE and DAMGO on stratum oriens interneurons during the blockade of $I_{\mathrm{h}}$ by extracellular cesium or ZD 7288. A protocol similar to the one described for the barium experiments was used except that, in each case, the concentration of cesium or ZD 7288 was increased until a complete block of $I_{\mathrm{h}}$ was achieved (cesium, 3-9 mM; ZD 7288, 25-100 $\mu \mathrm{M}$ ). At a voltage-clamp potential of $-66 \mathrm{mV}$, cesium inhibited the opioidinduced outward current in every cell that was examined $(n=6)$ (Fig. 10A). On average, cesium inhibited this response by $58.1 \pm$ $10.8 \%(p<0.01$; paired Student's $t$ test) (Fig. 11), suggesting that the inhibition of $I_{\mathrm{h}}$ was partly responsible for the opioid-induced change in holding current. In addition, as reported above, the application of cesium alone generated outward currents that were similar in magnitude to those caused by the opioids during barium application. This observation suggests that the inhibition of inward current associated with $I_{\mathrm{h}}$ by both cesium and the opioids was partially responsible for the holding current changes. When the interneurons were treated with a combination of barium (2 $\mathrm{mM}$ ) and cesium (3-9 $\mathrm{mm})$, the opioid-induced outward currents were blocked nearly completely $(14.6 \pm 7.5 \%$ of control, $n=6)$ (Fig. 11), and there was no effect of the opioids on the $I / V$ relationship.

As reported above, under control conditions the opioid ago- 
A

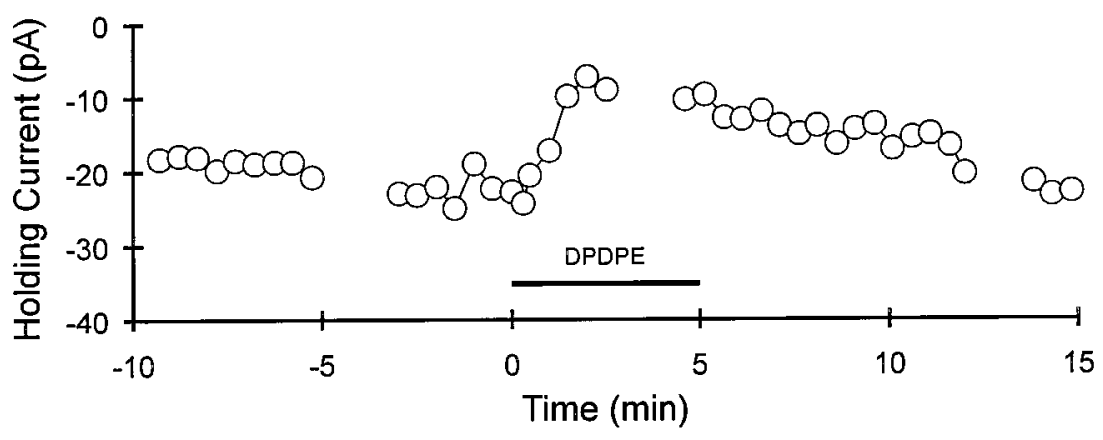

B

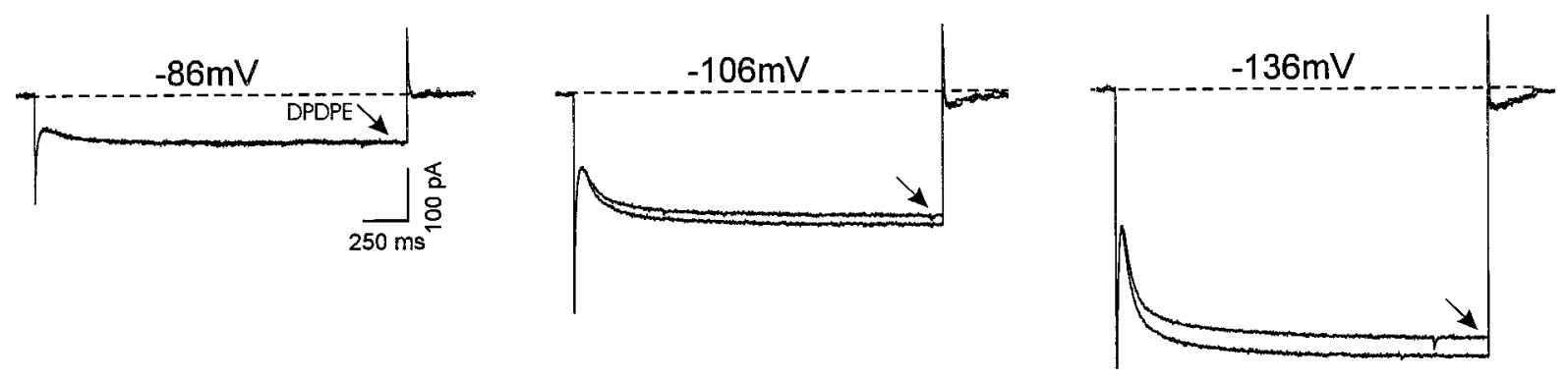

C

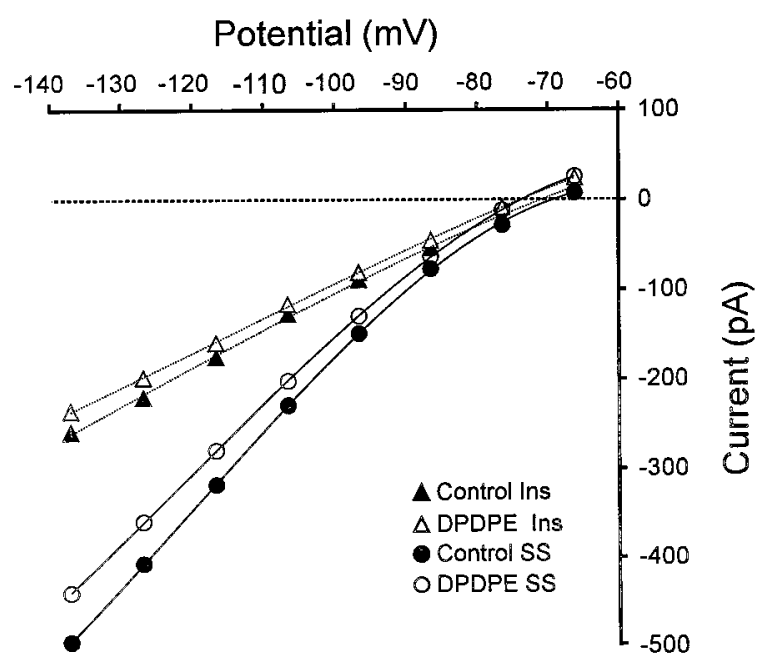

D

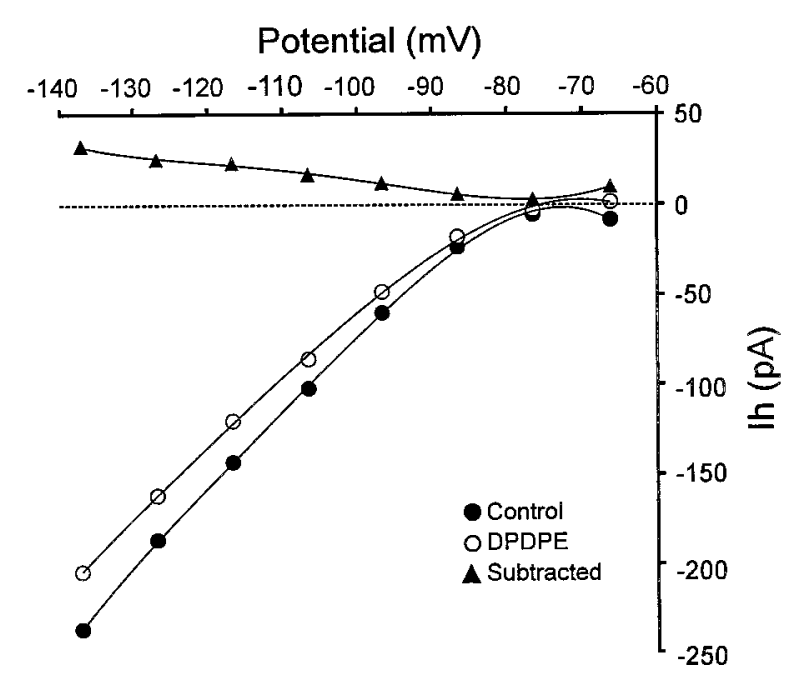

Figure 6. The $\delta$-opioid agonist DPDPE inhibits $I_{\mathrm{h}}$ in a stratum oriens interneuron. $A$, DPDPE-induced $(1 \mu \mathrm{M})$ outward current in a cell voltage-clamped at $-66 \mathrm{mV}$. Gaps in the data record are attributable to the construction of $I / V$ curves. $B$, Current responses evoked by selected 2 sec hyperpolarizing voltage steps before and during DPDPE (arrow) application. $C$, Effect of DPDPE on instantaneous and steady-state $I / V$ relationships. Note that, similar to ZD 7288 and cesium (see Fig. 5), DPDPE caused a greater reduction of the steady-state versus the instantaneous current at voltage steps hyperpolarized to approximately $-85 \mathrm{mV}$. $D$, Effect of DPDPE on $I_{\mathrm{h}}$ isolated by using the procedure described in Results. Note that DPDPE caused a voltage-dependent reduction in this current and that the opioid-induced inhibition was qualitatively similar to that observed with cesium and ZD 7288 (see Fig. 5). Similar effects also were seen with the $\mu$-opioid agonist DAMGO. 

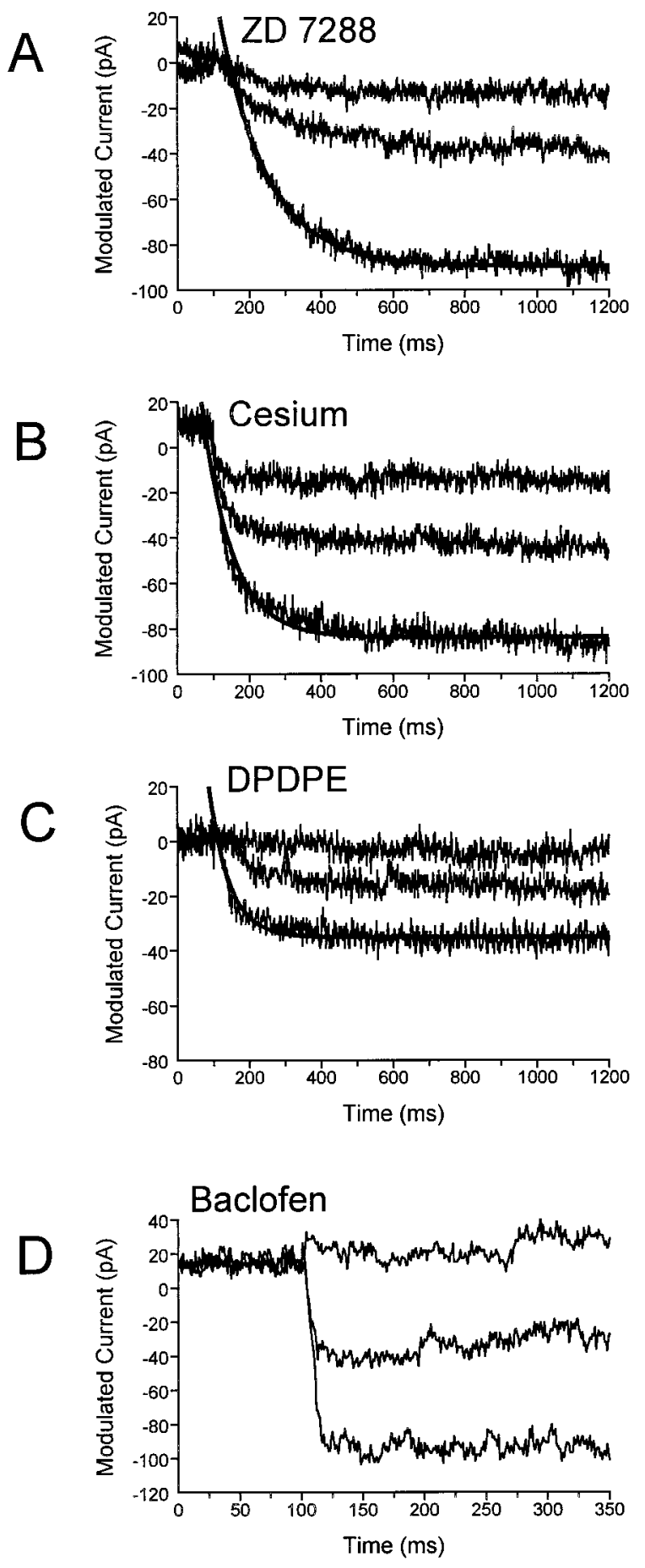

Figure 7. Currents inhibited by ZD 7288, cesium, and DPDPE share similar time and voltage dependence. The currents shown in $A-C$ were obtained by subtracting traces obtained during the application of the indicated modulator from control traces, using $2 \mathrm{sec}$ hyperpolarizing voltage steps to $-86,-106$, and $-136 \mathrm{mV}$. Each trace thus represents the current that was inhibited by ZD $7288(25 \mu \mathrm{M})$, cesium $(5 \mathrm{mM})$, or DPDPE $(1 \mu \mathrm{M})$ at these step potentials. The currents obtained at the $-136 \mathrm{mV}$ voltage steps then were fit by using exponential time constants (see Results) and are indicated by the solid lines. A, Currents inhibited by ZD 7288 exhibit typical $I_{\mathrm{h}}$ voltage and time dependence $(\tau=269 \mathrm{msec})$. $B$, Currents inhibited by cesium $(\tau=242 \mathrm{msec})$. $C$, Currents inhibited by DPDPE $(\tau=266 \mathrm{msec})$. $D$, Currents activated by baclofen $(60 \mu \mathrm{M})$ were obtained by subtracting the traces obtained during the drug from those obtained under control conditions. In this experiment $500 \mathrm{msec}$ hyperpolarizing voltage steps to $-86,-106$, and $-136 \mathrm{mV}$ were used. Note that nists DPDPE and DAMGO caused small decreases in the wholecell membrane conductance measured at a holding potential of $-66 \mathrm{mV}$ (see Figs. 2B, 10B). However, during the cesium block of $I_{\mathrm{h}}$ this decrease in conductance was converted to an increase (from $4.1 \pm 1.0 \mathrm{nS}$ to $5.3 \pm 1.3 \mathrm{nS} ; n=6$ ) (see Fig. 10B). Furthermore, this increase in conductance was associated with a current that reversed near the predicted $E_{\mathrm{rev}}$ for $\mathrm{K}^{+}$ions (measured $E_{\mathrm{rev}}=-101 \pm 6.1 \mathrm{mV}$; predicted $E_{\mathrm{K}}=-96 \mathrm{mV}$ ), suggesting that in the absence of $I_{\mathrm{h}}$ the opioid activation of $\mathrm{K}^{+}$channels was evident. Similar results were obtained in three interneurons when the selective blocker of $I_{\mathrm{h}}, \mathrm{ZD} 7288$, was used. In these cells the opioid-induced current also reversed near the predicted $E_{\mathrm{K}}$ (measured $E_{\text {rev }}=-99.7 \pm 9.0 \mathrm{mV}$ ).

A previous study has suggested that extracellular cesium can reduce the inward component of the baclofen-activated $\mathrm{K}^{+}$current observed at step potentials more negative than approximately $-110 \mathrm{mV}$ without affecting baclofen-induced outward currents (Sodickson and Bean, 1996). Therefore, in the present study the magnitude of the opioid-induced increase in $G_{\text {irk }}$ in the presence of cesium probably was underestimated. Moreover, the observation that cesium did not alter the outward currents produced by baclofen implies that the opioid-induced outward currents caused by $\mathrm{K}^{+}$channel activation similarly were unaffected by cesium and that the cesium attenuation of the opioid-induced outward currents likely was attributable to the blockade of $I_{\mathrm{h}}$. These findings, considered together, suggest that the opioids activate a $\mathrm{K}^{+}$conductance and inhibit $I_{\mathrm{h}}$ in the same stratum oriens interneurons and that both of these conductances contribute to the holding current changes seen at a holding potential of $-66 \mathrm{mV}$.

\section{DISCUSSION}

The results of this study demonstrate that opioid agonists selective for either $\mu$ - or $\delta$-receptors can generate outward currents in hippocampal stratum oriens interneurons. This would result in membrane hyperpolarization and the inhibition of these cells, which is consistent with the effects of opioids on neuronal populations throughout the CNS (Williams et al., 1982; Madison and Nicoll, 1988; North, 1989; Wimpey and Chavkin, 1991; Johnson and North, 1992). However, our results diverge from these previous studies in that this effect is not associated with an increase in membrane conductance and the apparent activation of $\mathrm{K}^{+}$ channels under control conditions. Instead, our results indicate that the outward currents produced by the opioid agonists in the absence of channel blockers are associated with a small decrease in conductance. One explanation for these disparate findings is that, in stratum oriens interneurons, either the opioids modulate a different current than that described in other systems or they simultaneously act at more than one ion channel. The large contribution of $I_{\mathrm{h}}$ to the total membrane conductance (Maccaferri and McBain, 1996) and the previously described actions of the opioids on $G_{\text {irk }}$ made these currents prominent candidates for further investigation. The present results suggest that concomitant modulation of these ion channels can explain the ambiguous

the currents inhibited by ZD 7288, cesium, and DPDPE share similar time- and voltage-dependent properties, whereas the traces obtained in baclofen do not. The traces shown in $A$ and $B$ were obtained from the experiments illustrated in Figure 5. The data shown in $C$ were derived from the experiment shown in Figure 6, and those in $D$ are from Figure 3. All experiments were conducted at $V_{\text {hold }}=-66 \mathrm{mV}$. 
A1

B

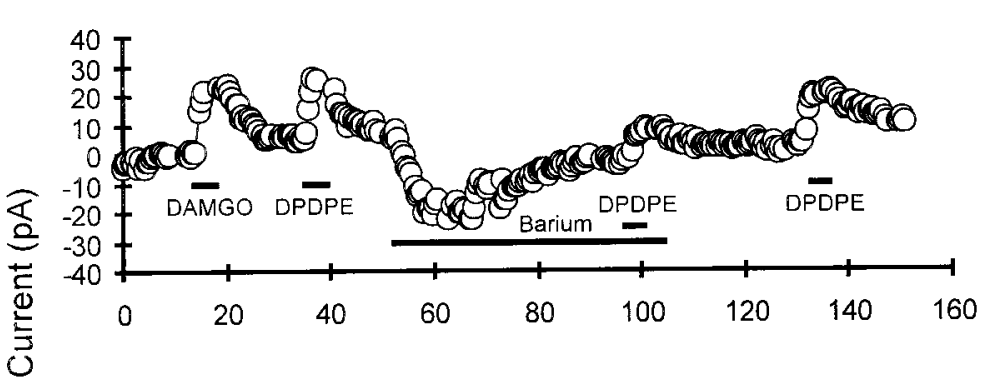

A2
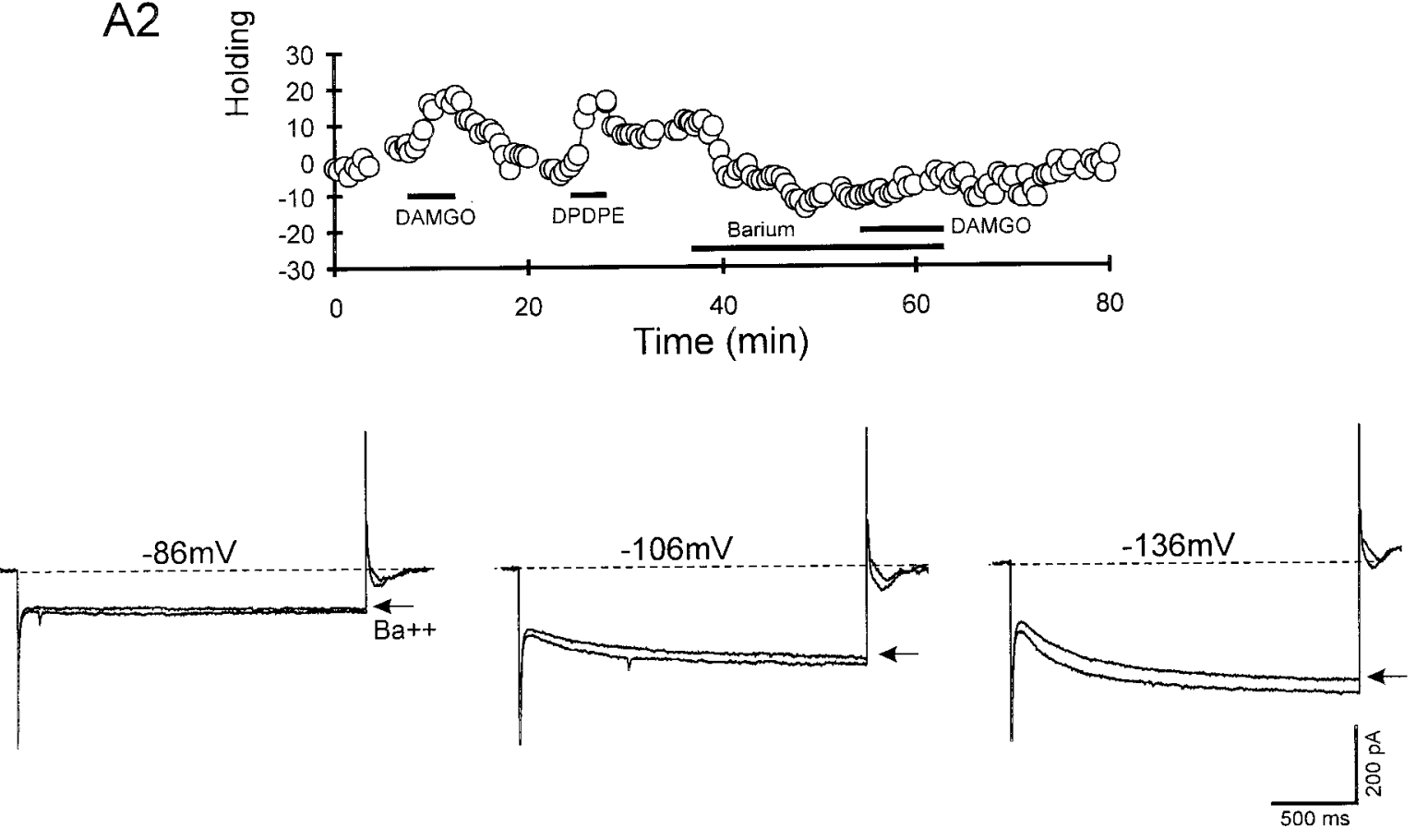

C

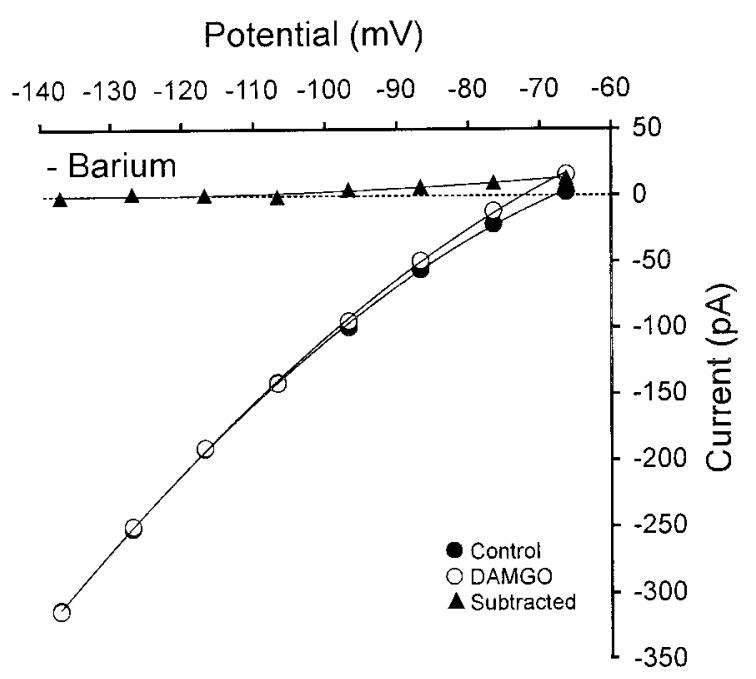

D

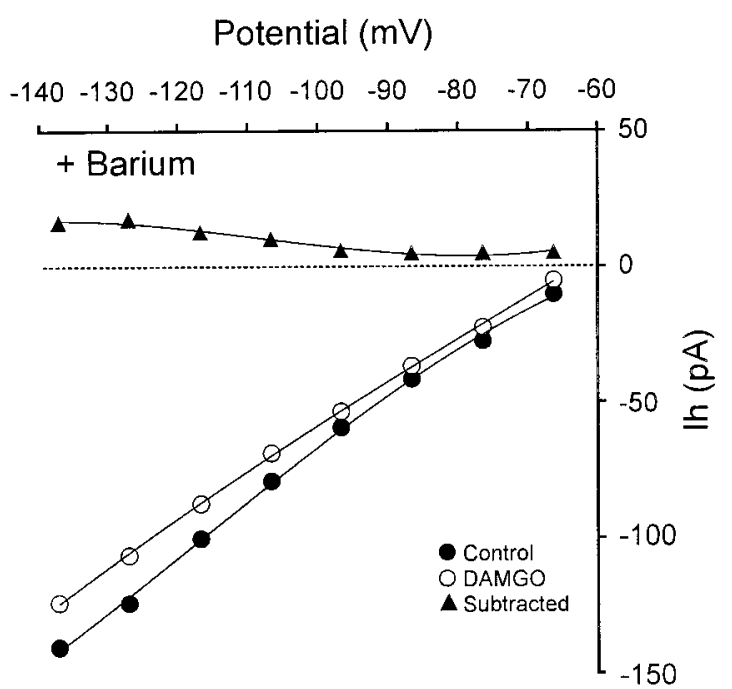

Figure 8. Blockade of $G_{\text {irk }}$ by barium reveals the opioid inhibition of $I_{\mathrm{h}}$ in stratum oriens interneurons. $A$, Time course of DAMGO- and DPDPE-induced (both at $1 \mu \mathrm{M}$ ) outward currents and inhibition by barium (2 mM). A1, A single experiment in which DAMGO and DPDPE generated outward currents. Barium reversibly reduced the outward current produced by DPDPE application. A2, Another neuron in which both DAMGO and DPDPE produced outward currents. The effect of DAMGO was nearly eliminated by barium in this cell. $B$, Effects of barium (arrows) on current responses at selected $2 \mathrm{sec}$ voltage steps. The holding current changes were subtracted to illustrate the effect of barium on the whole-cell conductance. The apparent reduction in the steady-state current produced by barium reversed near $E_{\mathrm{K}} . C$, Effect of DAMGO on the steady-state $I / V$ relationship in the absence of barium (same cell as $A 2$ ). $D$, Effect of DAMGO on the steady-state $I / V$ relationship during the application of $2 \mathrm{~mm}$ barium. Note the reduction in the whole-cell conductance caused by DAMGO. Similar results were observed with DPDPE. 
A

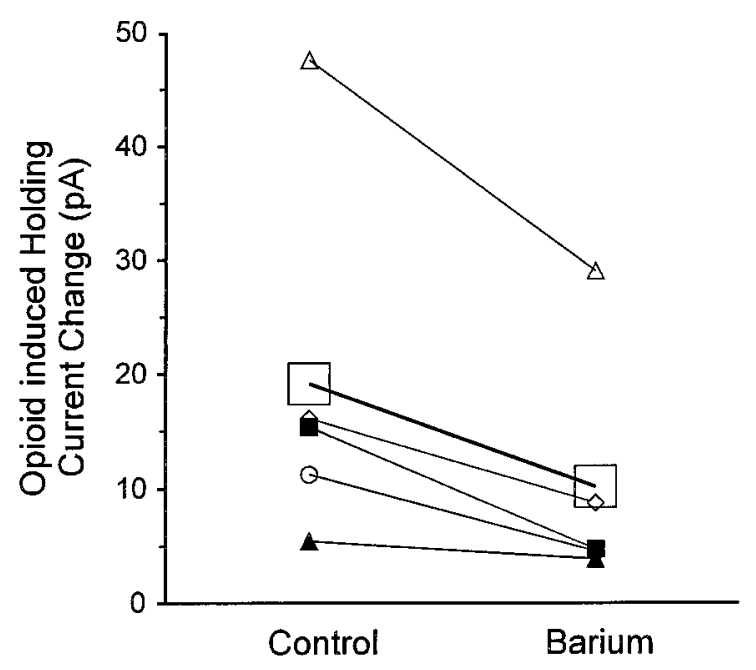

B

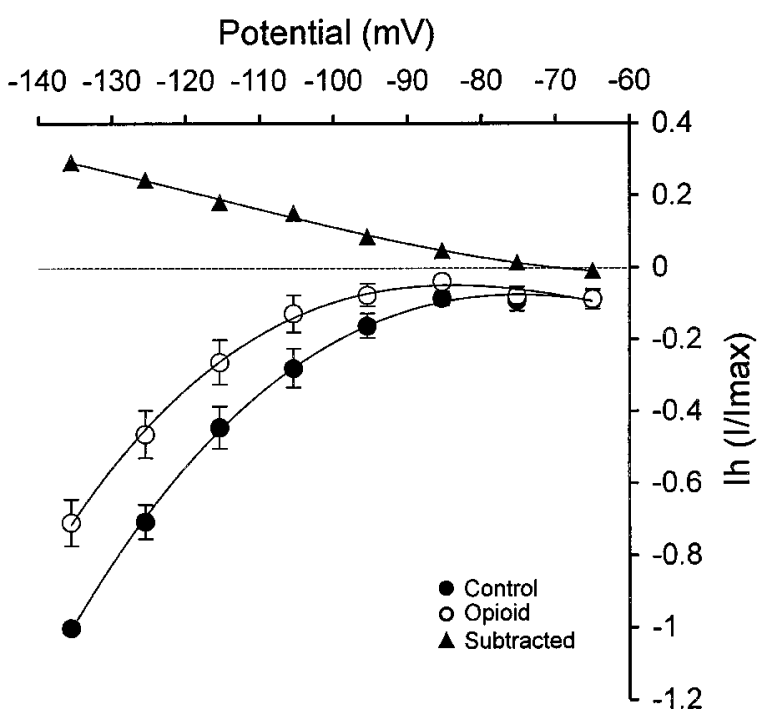

Figure 9. Opioid effects on stratum oriens interneurons after the blockade of $G_{\text {irk }}$ by barium. Experiments were conducted by using the protocol described in Figure 8. $A$, Opioid-induced (DAMGO or DPDPE, pooled data) outward currents in each neuron before (Control) and during barium application. Mean responses are indicated by $\square$. $B$, Mean \pm SEM effects of DAMGO and DPDPE (each at $1 \mu \mathrm{M}$, pooled data) on $I_{\mathrm{h}}$ normalized to the largest voltage step $(-136 \mathrm{mV})$ and isolated by using the procedure described in the Figure 5 legend. Note that the subtracted current is similar to that shown in Figure 5. In each experiment barium was applied for 20-50 min before opioid application.

effects of the opioids on the whole-cell conductance and that the outward currents produced by these agonists are the result of this modulation.

The properties of $I_{\mathrm{h}}$, as it has been described in the present study, are similar to those identified in this and many different neuronal and cardiac preparations (DiFrancesco, 1981; Halliwell and Adams, 1982; Mayer and Westbrook, 1983; McCormick and Pape, 1990; BoSmith et al., 1993; Ingram and Williams, 1994; Harris and Constanti, 1995; Maccaferri and McBain, 1996; Watts
A

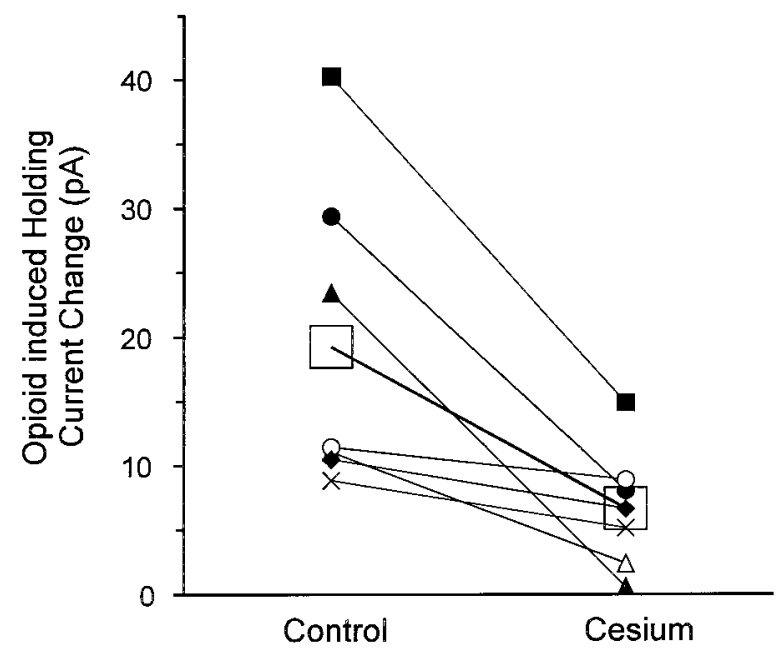

B

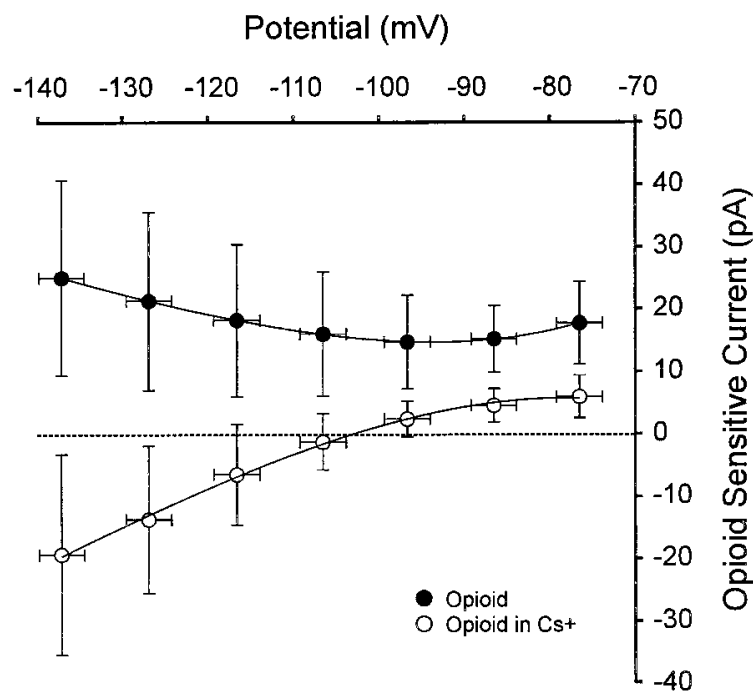

Figure 10. Opioid effects on stratum oriens interneurons during the blockade of $I_{\mathrm{h}}$ by extracellular cesium. In each neuron the opioid sensitivity was confirmed by examining the effect of either DPDPE or DAMGO on holding current. Then cesium (3-9 mM) was applied via bath superfusion until $I_{\mathrm{h}}$ was visibly blocked $(20-50 \mathrm{~min})$ and the effect of the opioid on holding current and the steady-state $I / V$ relationship was evaluated. $A$, Opioid-induced outward current in each interneuron produced before (Control) and during cesium application. The mean effects are indicated by $\square$. B , Mean \pm SEM opioid-sensitive current obtained from the subtracted $I / V$ curves before $(\bullet)$ and during cesium superfusion $(\bigcirc)$. The $E_{\text {rev }}$ of the opioid-sensitive current was $-101 \pm 6.1 \mathrm{mV}$, suggesting that it was carried by $\mathrm{K}^{+}$ions.

et al., 1996; Gasparini and DiFrancesco, 1997) (for review, see Pape, 1996). Among these characteristics are a reversal potential indicative of a mixed $\mathrm{Na}^{+} / \mathrm{K}^{+}$current, unique voltage and time dependency, and sensitivity to the blocking agents ZD 7288 and cesium. The evidence in support of the modulation $I_{\mathrm{h}}$ by the opioid agonists in the present study is derived from several observations, including (1) the shape of the $I / V$ relationship for the opioid-inhibited currents was similar to that obtained for $I_{\mathrm{h}}$, 


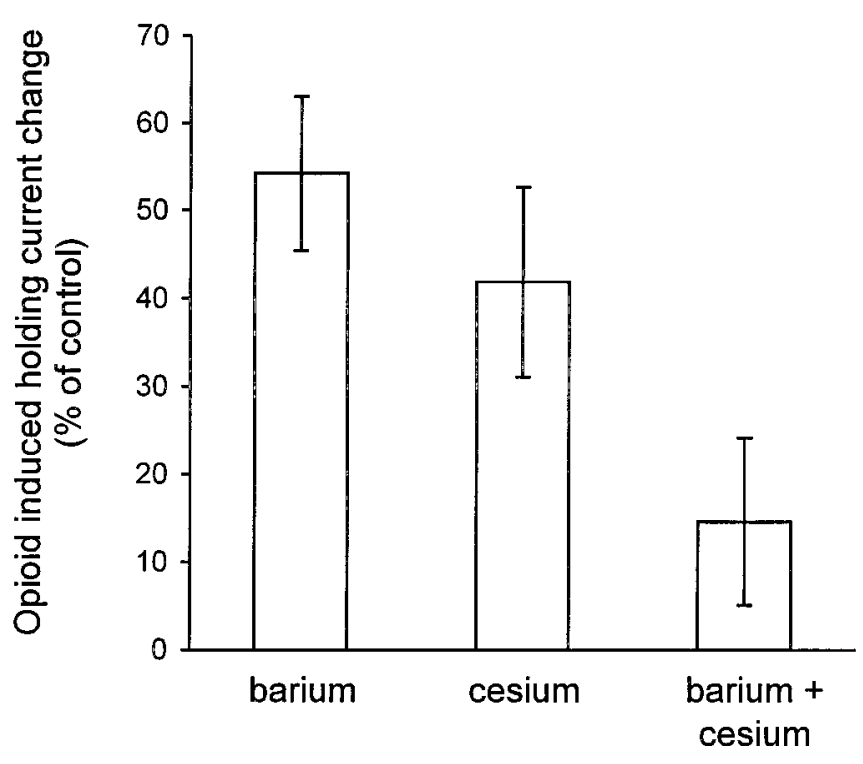

Figure 11. Effects of channel blockers on outward currents produced by opioid application (pooled data from $1 \mu \mathrm{M}$ DPDPE and DAMGO applications). The opioid-induced outward currents obtained in the presence of the blocking agent were expressed as a percentage of those obtained under control conditions. In each case there was a significant reduction in the outward current $(p<0.01-0.05$; paired Student's $t$ test), and the effect of the combined application of barium and cesium was significantly larger than with each blocker alone $(p<0.01)$. Barium, $n=5$; cesium, $n=7$; barium and cesium, $n=6$ ).

as defined by cesium and ZD 7288; (2) the opioids reduced the magnitude of $I_{\mathrm{h}}$ and the rate at which it activates; (3) the opioids had a larger effect on the steady-state $I / V$ relationship, in which $I_{\mathrm{h}}$ is more fully active, versus the instantaneous relationship; (4) extracellular cesium and ZD 7288 blocked $I_{\mathrm{h}}$ and eliminated the opioid-induced decrease in membrane conductance. We also provide evidence that $\mathrm{K}^{+}$channels were modulated in the same interneurons by the opioid agonists after $I_{\mathrm{h}}$ was blocked by cesium or ZD 7288. Thus, the opioids clearly increased the whole-cell conductance under these conditions, and this was found to be the result of the activation of a current possessing a $E_{\mathrm{rev}}$ near $E_{\mathrm{K}}$. The activation of $G_{\text {irk }}$ and the inhibition of $I_{\mathrm{h}}$ by the opioids are similar to the effects of adenosine on mesopontine cholinergic neurons (Rainnie et al., 1994), suggesting that this dual modulation may be common to several inhibitory neuromodulators. Collectively, our data suggest that both $I_{\mathrm{h}}$ and $G_{\text {irk }}$ are modulated by opioids in the same interneurons and that the simultaneous activation of $G_{\text {irk }}$ and the inhibition of $I_{\mathrm{h}}$ by the opioid agonists results in outward currents and little or no change in the wholecell conductance.

In some cells the opioid modulation of $I_{\mathrm{h}}$ was apparent in the absence of the blockade of $G_{\text {irk }}$ by barium (e.g., Fig. 6), suggesting either that $G_{\text {irk }}$ was not coupled to opioid receptors in these neurons or that the coupling of the opioid receptor to $I_{\mathrm{h}}$ was greater. However, in the majority of interneurons the modulation of $I_{\mathrm{h}}$ was not obvious until the competing $\mathrm{K}^{+}$channel response was blocked by barium. Similarly, the sole activation of a $\mathrm{K}^{+}$ conductance was seen in a small number of cells that had little apparent $I_{\mathrm{h}}$ (e.g., Fig. 4), but rarely was seen in the absence of cesium blockade of $I_{\mathrm{h}}$. This was despite the fact that $\mathrm{K}^{+}$currents, presumably mediated by $G_{\text {irk }}$, could be activated in these same neurons by the application of baclofen. This implies that, whereas the opioids may modulate both $I_{\mathrm{h}}$ and $G_{\text {irk }}$, GABA B receptor activation appears to modulate only $G_{\text {irk }}$ in these cells. This contrasts with previous reports in which $I_{\mathrm{h}}$ was inhibited by baclofen directly or as the indirect result of $G_{\text {irk }}$ activation in dopaminergic neurons (Jiang et al., 1993; Watts et al., 1996). In the present study the opioid inhibition of $I_{\mathrm{h}}$ after the blockade of $G_{\text {irk }}$ by barium suggests that this action was direct, and not the consequence of $G_{\text {irk }}$ activation. In addition, the observation that both $\mathrm{GABA}_{\mathrm{B}}$ and opioid receptors could activate $G_{\text {irk }}$, whereas only the opioids inhibited $I_{\mathrm{h}}$, suggests that these effects may occur via coupling to different G-proteins. Alternatively, both $\mathrm{GABA}_{\mathrm{B}}$ and opioid receptors may activate $\mathrm{K}^{+}$channels via a shared set of G-proteins, but opioid receptors may use a different pool of G-proteins to modulate $I_{\mathrm{h}}$.

Enkephalins are thought to be the endogenous opioid receptor ligands in the CA1 region of the hippocampus, where they are synthesized by some interneurons (Gall et al., 1981). Furthermore, axon terminals containing leu-enkephalin have been found apposed to GABA-positive cell bodies, dendrites, and axon terminals in this brain area (Commons and Milner, 1996). Localization of opioid receptors, using antibodies raised against the cloned $\mu$-, $\delta$-, and $\kappa$-opioid receptors, has shown that only $\mu$ - and $\delta$-receptors are expressed in the CA1 region of the hippocampus in appreciable concentrations (Mansour et al., 1995, 1996; Commons and Milner, 1997). Moreover, both of these receptors are distributed widely in this brain area, with the $\delta$-opioid receptor found to be associated with GAD-positive interneurons at particularly high levels in stratum oriens (Commons and Milner, 1997). The high selectivity of DAMGO and DPDPE for these receptor subtypes at the concentrations used in this study is well established (Mosberg et al., 1983; Cotton et al., 1985; Goldstein and Naidu, 1989; Lupica, 1995). This information and the observation that only $27 \%$ of the interneurons responding to either DPDPE or DAMGO also responded to the alternate agonist suggest that these peptides were selective for their respective receptor subtypes in the present study. In addition, the finding that outward currents were generated in the majority of interneurons by either DPDPE or DAMGO suggests that most stratum oriens interneurons express either $\mu$ - or $\delta$-opioid receptors and that some of these cells express both receptor subtypes. Together, these data provide anatomical and pharmacological substrates for the previously described physiological actions of the opioids in the hippocampus, including the activation of $G_{\text {irk }}$, the activation of an outward rectifier $\mathrm{K}^{+}$current, and the presynaptic inhibition of GABA release (Madison and Nicoll, 1988; Wimpey and Chavkin, 1991; Cohen et al., 1992; Lupica, 1995). All of these opioid actions ultimately diminish the release of GABA from these interneurons, thereby increasing the excitability of the pyramidal cells on which they impinge. The inhibition of $I_{\mathrm{h}}$ by opioid receptors may provide an additional site to reduce the excitability of the interneurons and alter the activity of the hippocampal network.

\section{Functional significance of $I_{\mathrm{h}}$ and $G_{\text {irk }}$ modulation by opioids}

The most reliable effect of the opioid agonists was to induce outward currents in the stratum oriens interneurons. This response could be produced via the activation of a current with a $E_{\text {rev }}$ negative to the holding potential (e.g., $G_{\text {irk }}$ ) or by the inhibition of a current with an $E_{\text {rev }}$ positive to the holding potential (e.g., $I_{\mathrm{h}}$ ). The observations that barium and cesium each reduced the opioid-induced outward currents to a similar degree and that their combined application nearly completely blocked 
these responses suggest that both $I_{\mathrm{h}}$ and $G_{\text {irk }}$ contributed to the holding current changes. Moreover, the observation that cesium alone could generate outward currents similar in magnitude to those caused by the opioids in the presence of barium suggests that $I_{\mathrm{h}}$ is activated partially at the clamp potential of $-66 \mathrm{mV}$ and that the opioids may generate outward currents via the inhibition of these ion channels. Current-clamp experiments in several laboratories have indicated that the blockade of $I_{\mathrm{h}}$ by ZD 7288 or cesium can result in the hyperpolarization of neurons held near the resting membrane potential (Harris and Constanti, 1995; Maccaferri and McBain, 1996; Gasparini and DiFrancesco, 1977). However, although resting membrane potentials were not recorded routinely in the present study, others have reported these values to range between approximately $-52 \mathrm{mV}$ and -66 $\mathrm{mV}$ in stratum oriens interneurons (Lacaille et al., 1987; McBain et al., 1994; Bergles et al., 1996). Furthermore, Maccaferri and McBain (1996) demonstrated in these same interneurons that $I_{\mathrm{h}}$ made a substantial contribution to the membrane conductance when the cells were held at $-60 \mathrm{mV}$, which is likely close to rest. These data suggest the possibility that the inward current contributed by $I_{\mathrm{h}}$ may help to set the resting membrane potentials of these cells at more depolarized levels.

In addition to its possible contribution to the membrane potential, the inhibition of $I_{\mathrm{h}}$ by the opioids also would tend to make these GABAergic interneurons less responsive to excitatory inputs, particularly at hyperpolarized potentials. Also, the unusual property of the activation of this inward current on hyperpolarization implies that one of its functions might be to oppose the influences of inhibitory (i.e., hyperpolarizing) neuromodulators. Thus, the reduction in neuronal excitability caused by the activation of $\mathrm{K}^{+}$channels and the subsequent membrane hyperpolarization initiated by the opioids and other inhibitory modulators might be reversed substantially by $I_{\mathrm{h}}$. Because of this possibility we hypothesize that the concurrent modulation of $I_{\mathrm{h}}$ and $G_{\text {irk }}$ in the same cells may help to maintain decreased excitability by preventing $I_{\mathrm{h}}$ from returning the membrane potential closer to action potential threshold. These combined actions would ensure that the inhibition of interneuron activity and GABA release initiated by $\mathrm{K}^{+}$channel activation would not be diminished by the repolarizing influences of $I_{\mathrm{h}}$.

\section{REFERENCES}

Bal T, McCormick DA (1996) What stops synchronized thalamocortical oscillations? Neuron 17:297-308.

Bergles DE, Doze VA, Madison DV, Smith SJ (1996) Excitatory actions of norepinephrine on multiple classes of hippocampal CA1 interneurons. J Neurosci 16:572-585.

BoSmith RE, Briggs I, Sturgess NC (1993) Inhibitory actions of ZENECA ZD 7288 on whole-cell hyperpolarization-activated inward current $\left(I_{\mathrm{h}}\right)$ in guinea pig-dissociated sinoatrial node cells. Br J Pharmacol 110:343-349.

Childers SR (1993) Opioid receptor-coupled second messenger systems. In: Handbook of experimental pharmacology: opioids, Vol I (Herz A, ed), pp 189-216. New York: Springer.

Christie MJ, North RA (1988) Agonists at $\mu$-opioid, M2-muscarinic, and $\mathrm{GABA}_{\mathrm{B}}$ receptors increase the same potassium conductance in rat lateral parabrachial neurones. Br J Pharmacol 95:896-902.

Cohen GA, Doze VA, Madison DV (1992) Opioid inhibition of GABA release from presynaptic terminals of rat hippocampal interneurons. Neuron 9:325-335.

Commons KG, Milner TA (1996) Ultrastructural relationships between leu-enkephalin- and GABA-containing neurons differ within the hippocampal formation. Brain Res 724:1-15.

Commons KG, Milner TA (1997) Localization of delta opioid receptor immunoreactivity in interneurons and pyramidal cells in the rat hippocampus. J Comp Neurol 381:373-387.
Cotton R, Kosterlitz HW, Paterson SJ, Rance MJ, Traynor JR (1985) The use of $\left[{ }^{3} \mathrm{H}\right]-\left[\mathrm{D}-\mathrm{Pen}^{2}, \mathrm{D}-\mathrm{Pen}^{5}\right]$ enkephalin as a highly selective ligand for the delta-binding site. Br J Pharmacol 84:927-932.

DiFrancesco D (1981) A study of the ionic nature of the pacemaker current in calf Purkinje fibres. J Physiol (Lond) 314:377-393.

Freund TF, Buzsáki G (1996) Interneurons of the hippocampus. Hippocampus $6: 347-470$.

Frötscher M, Leranth C, Lubbers K, Oertel WH (1984) Commissural afferents innervate glutamate decarboxylase immunoreactive nonpyramidal neurons in the guinea pig hippocampus. Neurosci Lett 46:137-143.

Gahwiler BH, Brown DA (1985) GABA $_{\mathrm{B}}$-receptor-activated $\mathrm{K}^{+}$current in voltage-clamped $\mathrm{CA}_{3}$ pyramidal cells in hippocampal cultures. Proc Natl Acad Sci USA 82:1558-1562.

Gall C, Brecha N, Karten HJ, Chang KJ (1981) Localization of enkephalin-like immunoreactivity to identified axonal and neuronal populations of the rat hippocampus. J Comp Neurol 198:335-350.

Gasparini S, DiFrancesco D (1997) Action of the hyperpolarizationactivated current $\left(I_{\mathrm{h}}\right)$ blocker ZD 7288 in hippocampal CA1 neurons. Pflügers Arch 435:99-106.

Goldstein A, Naidu A (1989) Multiple opioid receptors: ligand selectivity profiles and binding site signatures. Mol Pharmacol 36:265-272.

Halliwell JV, Adams PR (1982) Voltage-clamp analysis of muscarinic excitation in hippocampal neurons. Brain Res 250:71-92.

Harris NC, Constanti A (1995) Mechanism of block by ZD 7288 of the hyperpolarization-activated inward rectifying current in guinea pig substantia nigra neurons in vitro. J Neurophysiol 74:2366-2378.

Hille B (1992) Ionic channels of excitable membranes. Sunderland, MA: Sinauer.

Ingram SL, Williams JT (1994) Opioid inhibition of $I_{\mathrm{h}}$ via adenylyl cyclase. Neuron 13:179-186.

Inoue M, Matsuo T, Ogata N (1985) Characterization of pre- and postsynaptic actions of (-)-baclofen in the guinea-pig hippocampus in vitro. Br J Pharmacol 84:843-851.

Jiang Z-G, Pessia M, North RA (1993) Dopamine and baclofen inhibit the hyperpolarization-activated cation current in rat ventral tegmental neurones. J Physiol (Lond) 462:753-764.

Johnson SW, North RA (1992) Opioids excite dopamine neurons by hyperpolarization of local interneurons. J Neurosci 12:483-488.

Kunkel DD, Hendrickson AE, Schwartzkroin PA (1986) GAD immunocytochemistry of developing rabbit hippocampus. J Neurosci 6:541-552.

Lacaille JC, Mueller AL, Kunkel DD, Schwartzkroin PA (1987) Local circuit interactions between oriens/alveus interneurons and CA1 pyramidal cells in hippocampal slices: electrophysiology and morphology. J Neurosci 7:1979-1993.

Lambert NA, Wilson WA (1996) High-threshold $\mathrm{Ca}^{2+}$ currents in rat hippocampal interneurones and their selective inhibition by activation of GABA ${ }_{\mathrm{B}}$ receptors. J Physiol (Lond) 492:115-127.

Lee HK, Dunwiddie TV, Hoffer BJ (1980) Electrophysiological interactions of enkephalins with neuronal circuitry in the rat hippocampus. II. Effects on interneuron excitability. Brain Res 184:331-342.

Lupica CR (1995) $\delta$ and $\mu$ enkephalins inhibit spontaneous GABAmediated IPSCs via a cyclic AMP-independent mechanism in the rat hippocampus. J Neurosci 15:737-749.

Lupica CR, Dunwiddie TV (1991) Differential effects of $\mu$ - and $\delta$-receptor selective opioid agonists on feedforward and feedback GABAergic inhibition in hippocampal brain slices. Synapse 8:237-248.

Lupica CR, Proctor WR, Dunwiddie TV (1992) Dissociation of $\mu$ and $\delta$ opioid receptor-mediated reductions in evoked and spontaneous synaptic inhibition in the rat hippocampus in vitro. Brain Res 593:226-238.

Maccaferri G, McBain CJ (1996) The hyperpolarization-activated current $\left(I_{\mathrm{h}}\right)$ and its contribution to pacemaker activity in rat CA1 hippocampal stratum oriens/alveus interneurones. J Physiol (Lond) 497:119-130.

Madison DV, Nicoll RA (1988) Enkephalin hyperpolarizes interneurones in the rat hippocampus. J Physiol (Lond) 398:123-130.

Mansour A, Fox CA, Burke S, Akil H, Watson SJ (1995) Immunohistochemical localization of the cloned $\mu$ opioid receptor in the rat CNS. J Chem Neuroanat 8:283-305.

Mansour A, Burke S, Pavlic RJ, Akil H, Watson SJ (1996) Immunohistochemical localization of the cloned kappa 1 receptor in the rat CNS and pituitary. Neuroscience 71:671-690.

Mayer ML, Westbrook GL (1983) A voltage-clamp analysis of inward (anomalous) rectification in mouse spinal sensory ganglion neurons. J Physiol (Lond) 340:19-45. 
McBain CJ, DiChiara TJ, Kauer JA (1994) Activation of metabotropic glutamate receptors differentially affects two classes of hippocampal interneurons and potentiates excitatory synaptic transmission. J Neurosci 14:4433-4445.

McCormick DA, Pape H-C (1990) Noradrenergic and serotonergic modulation of a hyperpolarization-activated cation current in thalamic relay neurones. J Physiol (Lond) 431:319-342.

Miller KK, Hoffer A, Svoboda KR, Lupica CR (1997) Cholecystokinin increases GABA release by inhibiting a resting $\mathrm{K}^{+}$conductance in hippocampal interneurons. J Neurosci 17:4994-5003.

Moises HC, Rusin KI, MacDonald RL (1994) $\mu$-Opioid receptormediated reduction of neuronal calcium current occurs via a $\mathrm{G}_{\mathrm{o}}$-type GTP-binding protein. J Neurosci 14:3842-3851.

Mosberg HI, Hurst R, Hruby VJ, Gee K, Yamamura HI, Galligan JJ, Burks TF (1983) Bis-penicillamine enkephalins possess highly improved specificity toward $\delta$-opioid receptors. Proc Natl Acad Sci USA 80:5871-5874.

Newberry NR, Nicoll RA (1985) Comparison of the action of baclofen with gamma-aminobutyric acid on rat hippocampal pyramidal cells in vitro. J Physiol (Lond) 360:161-185.

Nicoll RA, Alger BE, Jahr CE (1980) Enkephalin blocks inhibitory pathways in the vertebrate CNS. Nature 287:22-25.

North RA (1989) Drug receptors and the inhibition of nerve cells. Br J Pharmacol 98:13-28.

Pang K, Rose GM (1989) Differential effects of methionine ${ }^{5}$-enkephalin on hippocampal pyramidal cells and interneurons. Neuropharmacology 28:1175-1181.

Pape H-C (1996) Queer current and pacemaker: the hyperpolarizationactivated cation current in neurons. Annu Rev Physiol 58:299-327.

Rainnie DG, Grunze HCR, McCarley RW, Greene RW (1994) Adenosine inhibition of mesopontine cholinergic neurons: implications for EEG arousal. Science 263:689-692.
Siggins GR, Henriksen SJ, Chavkin C, Gruol D (1986) Opioid peptides and epileptogenesis in the limbic system: cellular mechanisms. In: Advances in neurology, Vol 44 (Delgado-Escueta Jr AV, Ward AA, Woodbury DM, Porter RJ, eds), pp 501-512. New York: Raven.

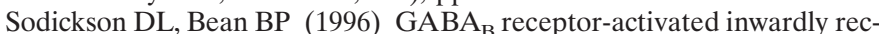
tifying potassium current in dissociated hippocampal CA3 neurons. J Neurosci 16:6374-6385.

Somogyi P, Smith P, Nunzi MG, Gorio A, Takagi H, Wu J-Y (1983) Glutamate decarboxylase immunoreactivity in the hippocampus of the cat: distribution of immunoreactive synaptic terminals with special reference to the axon initial segment of pyramidal neurons. J Neurosci 3:1450-1468.

Stevens KE, Shiotsu G, Stein L (1991) Hippocampal $\mu$-receptors mediate opioid reinforcement in the CA3 region. Brain Res 545:8-16.

Watts JE, Williams JT, Henderson G (1996) Baclofen inhibition of the hyperpolarization-activated cation current, $I_{\mathrm{h}}$, in rat substantia nigra zona compacta neurons may be secondary to potassium current activation. J Neurophysiol 76:2262-2270.

Williams JT, Egan TM, North RA (1982) Enkephalin opens potassium channels on mammalian central neurones. Nature 299:74-77.

Wimpey TL, Chavkin C (1991) Opioids activate both an inward rectifier and a novel voltage-gated potassium conductance in the hippocampal formation. Neuron 6:281-289.

Xie C-W, Lewis D (1991) Opioid-mediated facilitation of long-term potentiation at the lateral perforant path-dentate granule cell synapse. J Pharmacol Exp Ther 256:289-296.

Zhang L, McBain CJ (1995) Voltage-gated potassium currents in stratum oriens/alveus inhibitory neurones of the rat CA1 hippocampus. J Physiol (Lond) 488:647-660.

Zieglgansberger W, French ED, Siggins GR, Bloom FE (1979) Opioid peptides may excite hippocampal pyramidal neurons inhibiting adjacent inhibitory interneurons. Science 205:415-417. 